\title{
Trafficking and Fusion of Neuropeptide Y-Containing Dense-Core Granules in Astrocytes
}

\author{
Prabhu Ramamoorthy and Matthew D. Whim \\ Department of Biology, Pennsylvania State University, State College, Pennsylvania 16802
}

It is becoming clear that astrocytes are active participants in synaptic functioning and exhibit properties, such as the secretion of classical transmitters, previously thought to be exclusively neuronal. Whether these similarities extend to the release of neuropeptides, the other major class of transmitters, is less clear. Here we show that cortical astrocytes can synthesize both native and foreign neuropeptides and can secrete them in a stimulation-dependent manner. Reverse transcription-PCR and mass spectrometry indicate that cortical astrocytes contain neuropeptide Y (NPY), a widespread neuronal transmitter. Immunocytochemical studies reveal NPY-immunoreactive (IR) puncta that colocalize with markers of the regulated secretory pathway. These NPY-IR puncta are distinct from the synaptic-like vesicles that contain classical transmitters, and the two types of organelles are differentially distributed. After activation of metabotropic glutamate receptors and the release of calcium from intracellular stores, the NPY-IR puncta fuse with the cell membrane, and the peptidecontaining dense cores are displayed. To determine whether peptide secretion subsequently occurred, exocytosis was monitored from astrocytes expressing NPY-red fluorescent protein (RFP). In live cells, after activation of glutamate receptors, the intensity of the NPY-RFP-labeled puncta declined in a step-like manner indicating a regulated release of the granular contents. Because NPY is a widespread and potent regulator of synaptic transmission, these results suggest that astrocytes could play a role in the peptidergic modulation of synaptic signaling in the CNS.

Key words: large dense-core granule; astrocyte; peptide; secretion; neuropeptide Y; gliotransmitter

\section{Introduction}

Astrocytes are a prominent population of cells in the CNS that have diverse roles including regulation of the extracellular environment, provision of neurons with metabolites, modulation of synaptic transmission, and regulation of the vascular system (Haydon and Carmignoto, 2006). They also act as target cells that respond to small molecule ("classical") transmitters released from neurons (Bergles et al., 1997). In addition to acting as sensors of transmitter release, astrocytes themselves synthesize and release a variety of neuroactive molecules ("gliotransmitters") (Grandes et al., 1991) including glutamate, ATP, and D-serine, a behavior once thought characteristic of neurons (Schell et al., 1995; Mothet et al., 2005). Such glial-secreted molecules can modulate neuronal excitability and synaptic transmission through the activation of neuronal receptors (Kang et al., 1998; Fellin et al., 2004; Pascual et al., 2005). Although the mechanism(s) underlying secretion may involve membrane channels and transporters (Evanko et al., 2004), release can also occur via a calcium-mediated process involving the vesicular exocytosis of gliotransmitters (Innocenti et al., 2000; Pasti et al., 2001; Zonta et

\footnotetext{
Received Sept. 8, 2008; revised 0ct. 23, 2008; accepted Nov. 5, 2008.

This work was supported by National Institutes of Health Grant 5R21 NS047543 and by start-up funds from Pennsylvania State University (PSU). We thank Greg Mitchell for plasmid construction; Gong Chen, June Liu, and Greg Mitchell for critically reading this manuscript; Anne Stanley (Mass Spectrometry Core, PSU) for help with MALDI-TOF analysis; and R. Y. Tsien (University of California San Diego, La Jolla, CA) for the mRFP1 plasmid.

Correspondence should be addressed to Dr. Matthew D. Whim, Department of Biology, 208 Mueller Building,

Pennsylvania State University, State College, PA 16802. E-mail: mdw13@psu.edu.

D0I:10.1523/JNEUROSCI.5361-07.2008

Copyright $\odot$ 2008 Society for Neuroscience $\quad$ 0270-6474/08/2813815-13\$15.00/0
}

al., 2003). Many of the molecules that are needed for neuronal vesicular transmitter release, including soluble $N$-ethylmaleimidesensitive factor attachment protein receptor (SNARE) proteins, glutamate transporters, and synaptotagmin isoforms, have been found in astrocytes (Montana et al., 2004; Zhang et al., 2004a,b). These studies indicate that astrocytes can secrete small molecule transmitters.

How far do these glial-neuronal similarities extend? Do astrocytes also synthesize and release neuropeptide cotransmitters just like the majority of neurons? A variety of astrocytic neuropeptides have been identified (Michel et al., 1986; Shinoda et al., 1989; Melner et al., 1990; McKenzie et al., 1994; Barnea et al., 1998; Buzas et al., 1998), but the synthesis, trafficking, and release of these molecules has not been widely studied, and fundamental questions remain. In particular, are these neuropeptides synthesized and packaged via similar pathways to those identified in neurons? Are astrocytic neuropeptides colocalized with the small molecule gliotransmitters? Are glial neuropeptides secreted, and if so, does exocytosis occur through the regulated or constitutive secretory pathways?

Here we address these questions using mouse cortical astrocytes. We find that these cells are able to synthesize both foreign and native neuropeptides, including neuropeptide Y (NPY), a peptide widely distributed throughout the mammalian nervous system (Gray and Morley, 1986). Activation of metabotropic glutamate receptors results in a calcium-dependent fusion of NPYcontaining dense-core granules with the cell membrane and consequent peptide secretion. Therefore, astrocytes, like neurons, 

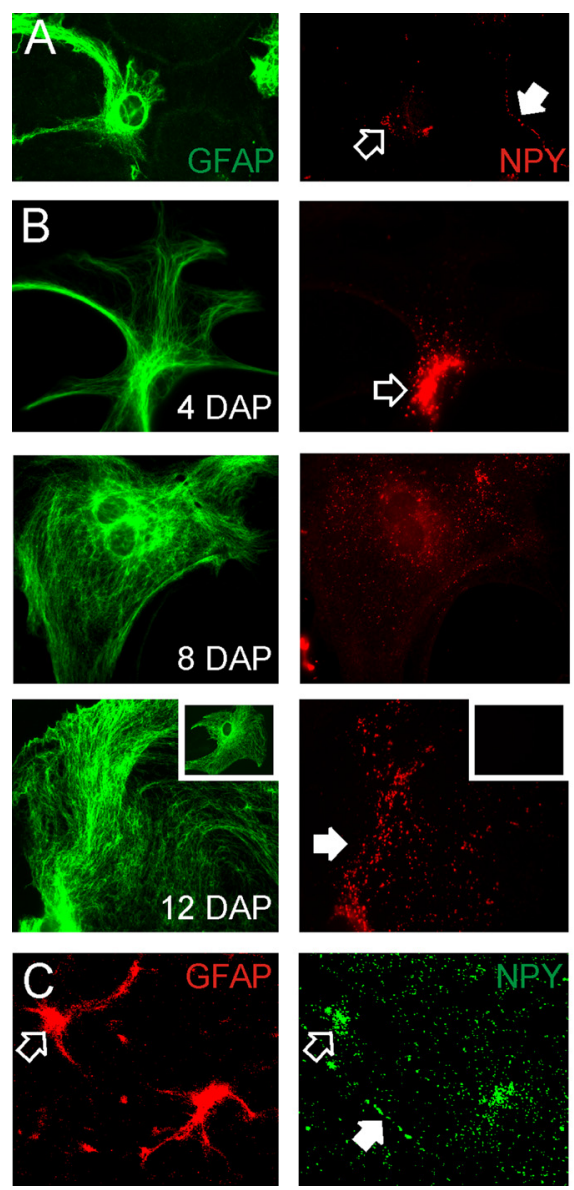
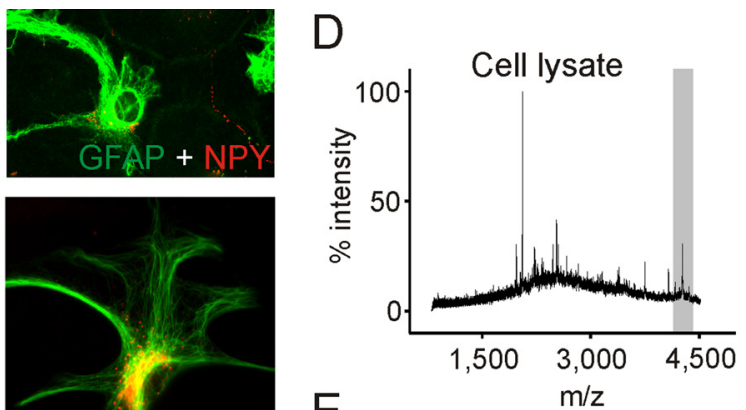

E
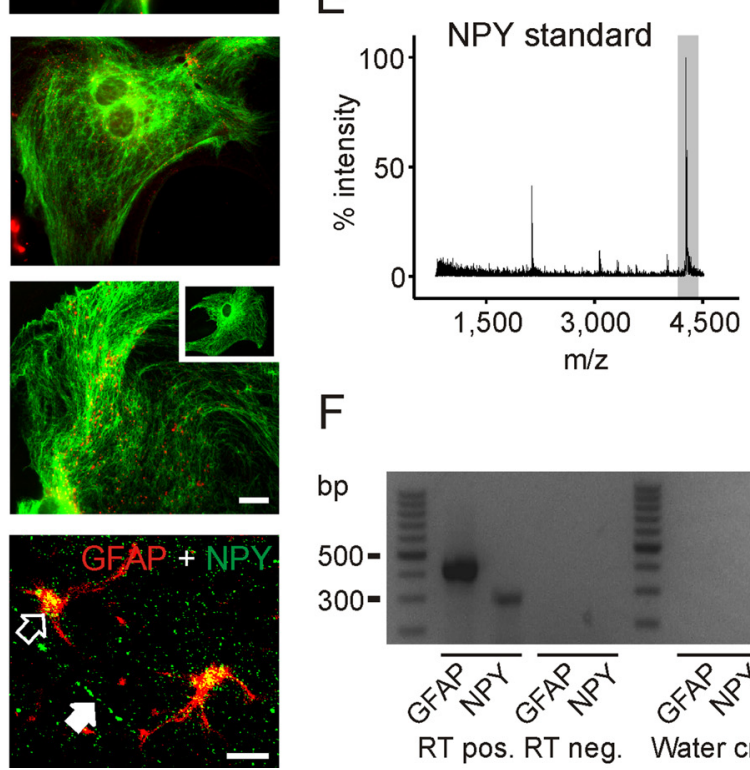

$\mathrm{F}$
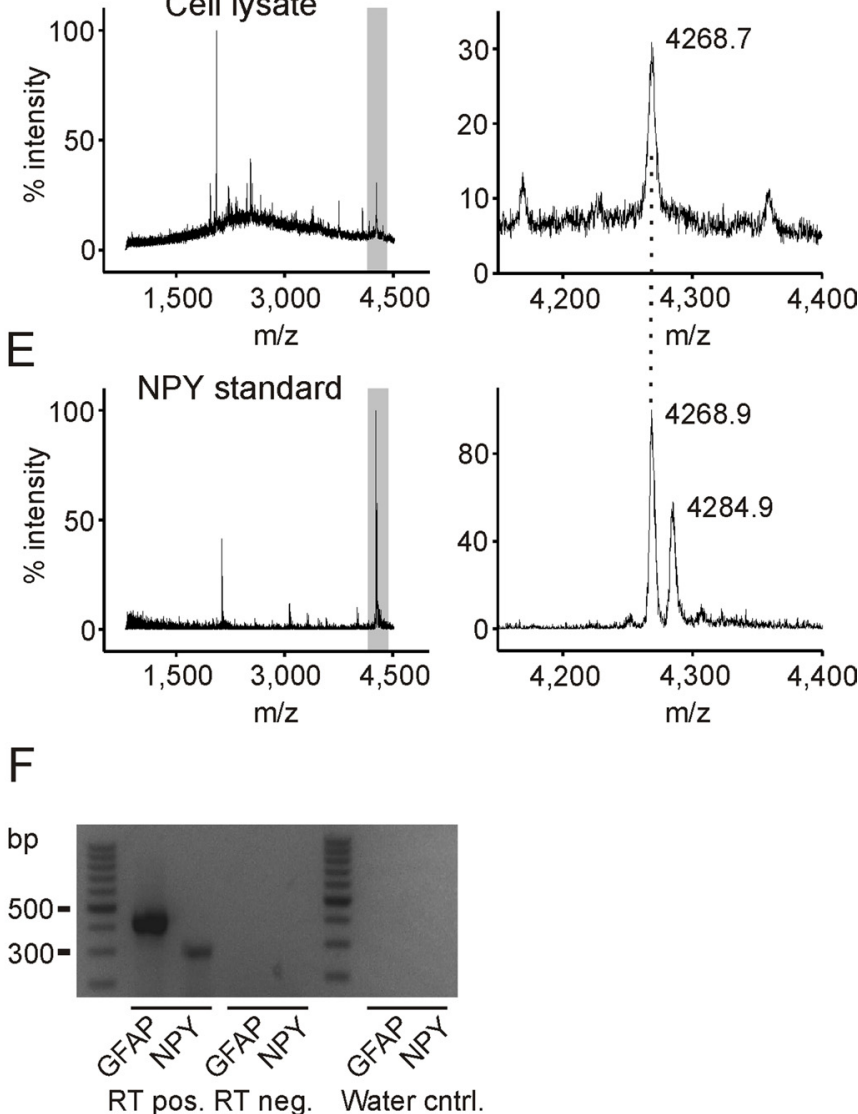

Figure 1. Identification of NPY in GFAP-positive astrocytes. $\boldsymbol{A}$, In cocultures of astrocytes and hippocampal neurons, punctate NPY immunoreactivity was observed in both neuronal processes (filled arrow) and astrocytes (open arrow). B. Similar NPY immunoreactivity was seen in purified astrocyte cultures. Astrocytes were double stained with antibodies for GFAP (left) and NPY (middle) at various times in cultures (DAP). NPY-IR puncta were observed in both perinuclear (open arrow) and pan-cytoplasmic (filled arrow) locations. Merged images are shown (right). Scale bar, $15 \mu \mathrm{m}$. The insets show that no NPY-IR staining was observed when the primary NPY antibody was omitted. C, Astrocytes in a brain slice showed staining for both GFAP and NPY (open arrows). Some NPY-IR neuronal processes were also present (filled arrows). Scale bar, $5 \mu \mathrm{m}$. D, Astrocytic lysate was subjected to MALDI-TOF mass spectrometry. A peak was found at $4268.7 \mathrm{~m} / \mathrm{z}$. Given the $\pm 0.1 \%$ nominal mass accuracy for this technique, this is consistent with the presence of NPY (theoretically $4271.7 \mathrm{~m} / \mathrm{z}$ ). E, MALDI-TOF of NPY (0.5 pmol) generated a signal at $4268.9 \mathrm{~m} / \mathrm{z}$, confirming the presence of NPY in the cell lysate in $\boldsymbol{D}$. A second peak was also apparent $(4284.9 \mathrm{~m} / \mathrm{z}$ ), which may be attributable to oxidation of the single methionine residue in NPY (leading to the observed $16 \mathrm{~m} / \mathrm{z}$ difference). The gray bars in $\boldsymbol{D}$ and $\boldsymbol{E}$ indicate the expanded regions shown on the right. Each spectrum was individually normalized to the largest peak. $\boldsymbol{F}$, RT-PCR of purified astrocyte cultures revealed the presence of NPY and GFAP mRNA. Amplicons were not produced from control reactions lacking either reverse transcriptase or nucleic acid. Water cntrl., Water control; RT pos., reverse transcriptase positive; RT neg., reverse transcriptase negative.

have a regulated secretory pathway(s) that is responsible for the release of multiple classes of transmitter molecules. Because NPY is a potent regulator of synaptic transmission (van den Pol et al., 1996) and NPY receptors are found throughout the CNS (Dumont et al., 2004), astrocytes may be involved in the peptidergic regulation of synaptic transmission.

\section{Materials and Methods}

Cell culture. Astrocytes were cultured from C57BL/6 mice [postnatal day 1 (P1) to P3] as described previously (McCarthy and de Vellis, 1980; Parpura et al., 1995). Briefly, cortical tissue was treated with trypsin (Sigma type XI) for $50 \mathrm{~min}$ at $37^{\circ} \mathrm{C}$ and dispersed by trituration. Cells were plated into tissue culture flasks and maintained at $37^{\circ} \mathrm{C}$ in culture medium (DMEM/10\% FBS) in a humidified 5\% $\mathrm{CO}_{2} / 95 \%$ air atmosphere. Once cultures became confluent (7-10 d) the flasks were shaken at $300 \mathrm{rpm}$ at $37^{\circ} \mathrm{C}$ in air, initially for $2 \mathrm{~h}$ and then after a complete exchange of medium for $18-20 \mathrm{~h}$ (repeated three times). The remaining cells were detached using trypsin/EDTA and plated on coverslips coated with poly-D-lysine. Purified astrocytes were used 1-12 d after plating (DAP; see Results). This procedure eliminated weakly adhesive cells including neurons and microglia. Staining with an anti-glial fibrillary acidic protein (GFAP) antibody (see below) indicated that $>70 \%$ of the cells were intensely GFAP immunoreactive. The lack of neurons in these cultures was confirmed by the absence of microtubule-associated protein (MAP) immunoreactivity, a neuronal dendritic marker. As a positive control, we confirmed that the MAP antibody stained dendritic processes in glial-neuronal cocultures (data not shown). Cocultures of astrocytes and neurons (see Fig. 1A) were derived from C57BL/6 mice (P1-P3). AtT-20 cells were cultured in DMEM/10\% FBS as described previously (Whim and Moss, 2001).

Reverse transcription-PCR. RNA was isolated from astrocytes growing on a single coverslip using TRIzol (Invitrogen), following the manufacturer's instructions. The pellet was dissolved in $25 \mu \mathrm{l}$ of water containing $1 \mu \mathrm{l}$ of RNasin $(40 \mathrm{U} / \mu \mathrm{l})$. A sample $(4 \mu \mathrm{l})$ was treated with DNase $(1 \mu \mathrm{l}$ of $10 \times$ buffer, $1 \mu \mathrm{l}$ of $1 \mathrm{U} / \mu \mathrm{l}$ DNase, $4 \mu \mathrm{l}$ of water) and sequentially incubated at $37^{\circ} \mathrm{C}$ for $30 \mathrm{~min}$ and at $65^{\circ} \mathrm{C}$ for $10 \mathrm{~min}$. Oligo(dT) 15 primer $(1 \mu \mathrm{l}, 0.5 \mu \mathrm{g} / \mu \mathrm{l})$ and water $(4 \mu \mathrm{l})$ were added, and the mixture was heated to $70^{\circ} \mathrm{C}$ for $5 \mathrm{~min}$ and cooled on ice. Reverse transcription was performed by incubation at $42^{\circ} \mathrm{C}$ for $60 \mathrm{~min}$ after the addition of $5 \mu \mathrm{l}$ of $5 \times$ buffer, $2 \mu \mathrm{l}$ of $12.5 \mathrm{~mm}$ dNTPs, $0.5 \mu \mathrm{l}$ of RNasin, $1 \mu \mathrm{l}$ of $200 \mathrm{U} / \mu \mathrm{l}$ Moloney murine leukemia virus reverse transcriptase, and $1.5 \mu \mathrm{l}$ of water. The reaction was then terminated by incubation at $95^{\circ} \mathrm{C}$ for $5 \mathrm{~min}$. PCR used previously described intron spanning primers for GFAP (Zhang et al., 2004b) and NPY (Fann and Patterson, 1993), except that the latter were 
slightly modified to account for differences between the rat and mouse sequences. The forward GFAP primer was 5'-GCCACGTTTCTCCTTGTCTCGA- $3^{\prime}$, and the reverse GFAP primer was $5^{\prime}$-GCTTCATGTGCCTCCTGTCTAT-3' (435 bp product). The forward NPY primer was $5^{\prime}$-GCTAGGTAACAAGCGAATGGGG- $3^{\prime}$, and the reverse NPY primer was $5^{\prime}$ CACATGGAAGGGTCTTCAAGC-3' (288 bp product). Each reaction contained $5 \mu$ l of $10 \times$ buffer, $2.5 \mu \mathrm{l}$ of $20 \mu \mathrm{M}$ each primer, $1 \mu \mathrm{l}$ of 5 $\mathrm{U} / \mu \mathrm{l} \mathrm{Taq}$ polymerase, $2.5 \mu \mathrm{l}$ of the reverse transcription reaction, and water to a final volume of $50 \mu \mathrm{l}$. The PCR protocol was $94^{\circ} \mathrm{C}$ for $45 \mathrm{~s}$, $55^{\circ} \mathrm{C}$ for $45 \mathrm{~s}$, and $72^{\circ} \mathrm{C}$ for $75 \mathrm{~s}$, for 36 cycles, and then $94^{\circ} \mathrm{C}$ for $60 \mathrm{~s}, 55^{\circ} \mathrm{C}$ for $45 \mathrm{~s}$, and $72^{\circ} \mathrm{C}$ for $75 \mathrm{~s}$. Samples $(20 \mu \mathrm{l})$ were analyzed on $2 \%$ agarose gels and photographed, and the images were inverted for clarity. Bands corresponding to the GFAP and NPY products were excised, and sequencing of the amplicons confirmed that both contained the expected products. Controls included omission of reverse transcriptase (to reveal any genomic contamination) and substitution of water for template
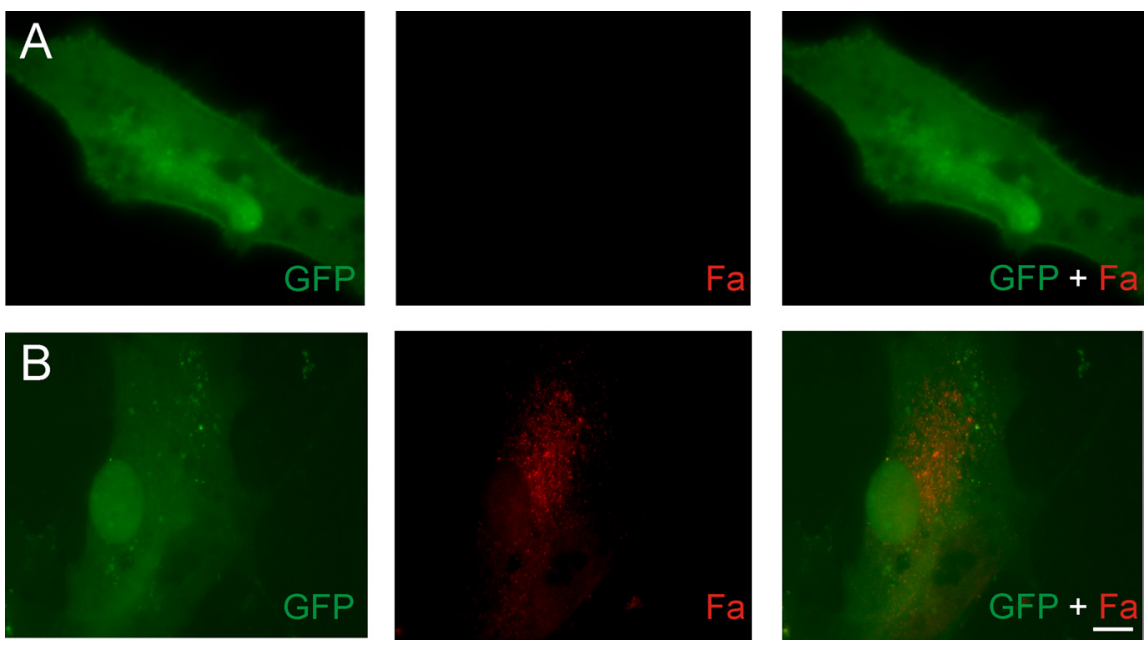

Figure 2. Astrocytes have a metabolic pathway enabling synthesis of foreign neuropeptides. $A$, Astrocytes (2 DAP) were transfected with pGFP and stained with an antibody to FMRFamide. None of the GFP-positive cells (left) showed FMRFamide (Fa) immunoreactivity (middle). B, Astrocytes (2 DAP) were transfected with pGFP and an FMRFamide-tagged NPY prohormone. An example of a GFP-positive cell (left) that was also FMRFamide immunoreactive (middle) is shown. The right panels show merged images. Scale bar, $15 \mu \mathrm{m}$.

After washing, the slices were mounted in Vectashield, and images were taken using an Olympus Fluoview 300 confocal microscope.

Primary antibodies used were mouse anti-GFAP (1:600; MAB3402; Millipore Bioscience Research Reagents), mouse anti-carboxypeptidase E (CPE) (1:600; 610758; BD Biosciences Transduction Laboratories), rabbit anti-NPY (1:200; T-4070; Peninsula Laboratories), sheep antiNPY (1:200; AB1583; Millipore Bioscience Research Reagents), rabbit anti-FMRFamide (1:200; IHC 8755; Peninsula Laboratories), guinea pig anti-VGLUT1 (1:1000; AB5905; Millipore Bioscience Research Reagents), guinea pig anti-vesicular GABA transporter (1:1000; AB5855; Millipore Bioscience Research Reagents), mouse anti-GM130 (1:1000; 610822; BD Biosciences Transduction Laboratories), and mouse antiMAP2 (1:200; MAB378; Millipore Bioscience Research Reagents). Secondary antibodies were swine anti-rabbit tetramethylrhodamine isothiocyanate (TRITC; 1:40; Dako), donkey anti-rabbit Alexa 488 (1:200; Invitrogen), and donkey anti-mouse TRITC, goat anti-mouse FITC, donkey anti-guinea pig FITC, donkey anti-rabbit TRITC, donkey antisheep TRITC (all 1:50; Jackson ImmunoResearch). For double-staining experiments, antibodies were applied sequentially with the anti-NPY antibody applied first. Control experiments showed there was no significant bleed-through of the fluorescent labels or cross-reactivity between antibodies. NPY-immunoreactive (IR) puncta were observed with both the rabbit NPY (Ma et al., 2006) and sheep NPY antibodies (Jinno et al., 2007). All presented data were generated using the former. Images were obtained with a Nikon TE2000U microscope with a $60 \times$ (1.4 numerical aperture) oil-immersion objective and a Retiga 1300 monochrome camera.

Secretion experiments. Coverslips with astrocytes were briefly washed with extracellular solution and subsequently incubated with agonists for varying amounts of time at RT. Cells were then fixed and processed for NPY immunoreactivity as detailed above, except that in most experiments the permeablization step was omitted (to reveal extracellular staining). To quantify the amount of secretion, the number of surface NPY-IR puncta in each condition was compared with the number of NPY-IR puncta in permeabilized cells prepared from the same culture. Thus, each experiment had its own internal positive control. Each experiment was repeated at least three times using independent cultures. In experiments to determine the loss of extracellular staining after agonist stimulation (see Fig. 7), the cells were washed in external solution and incubated for varying lengths of time before fixation. Most agonists were prepared as stock solutions in distilled water, except for BAPTA-AM and thapsigargin, which were prepared in DMSO and diluted into extracellular medium. In these experiments, the control cells were incubated in extracellular solution containing vehicle $(<0.23 \%$ DMSO $)$. 

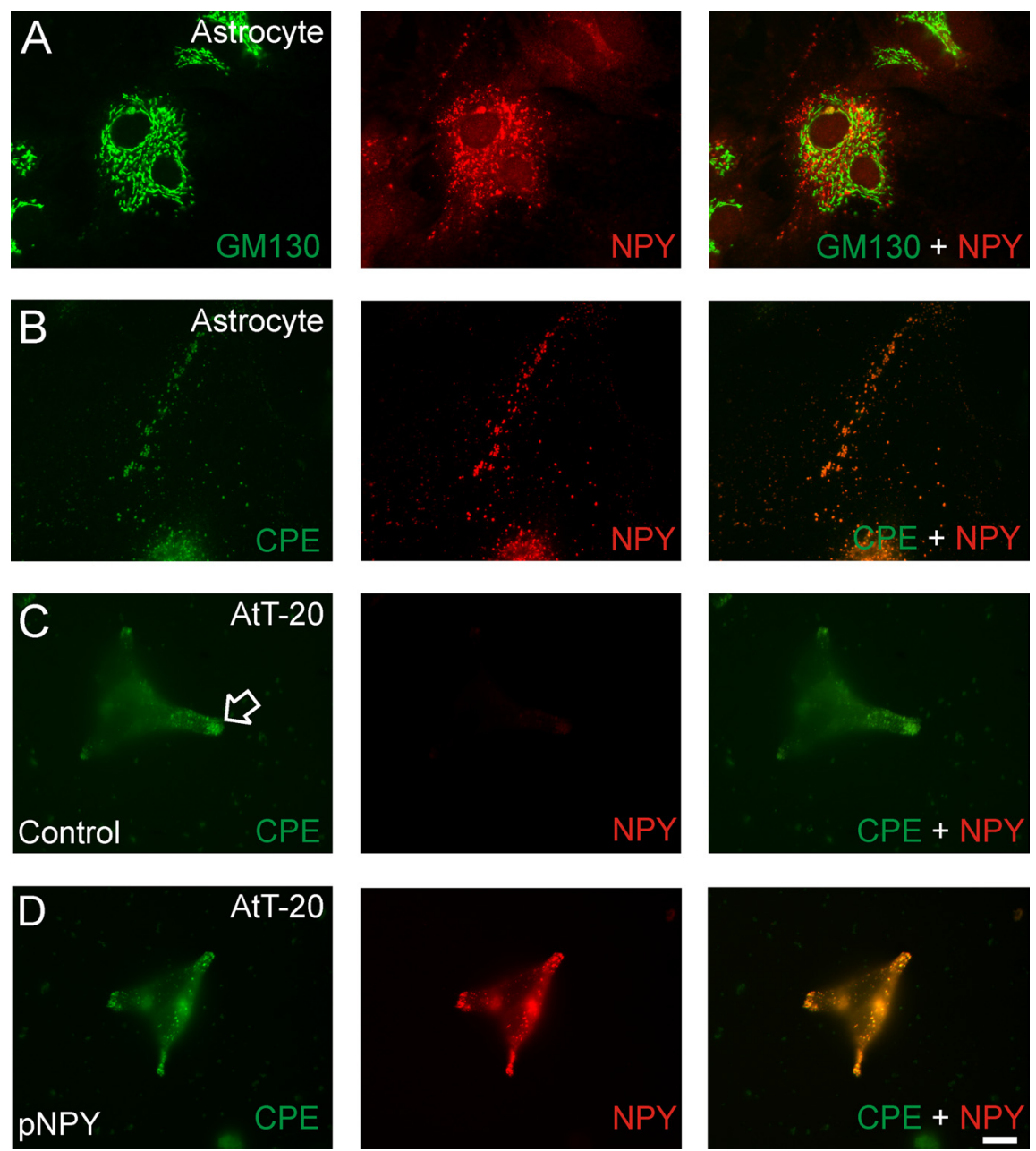

Figure 3. NPY-IR puncta colocalize with markers of the secretory pathway. $\boldsymbol{A}$, A marker of the cis-Golgi, GM130, stained a perinuclear region in cultured astrocytes that partially overlapped with NPY immunoreactivity. $\boldsymbol{B}$, Astrocytes were costained for CPE (left), a marker of dense-core granules, and NPY (middle). The right panel shows the merged image. CPE immunoreactivity was punctate and colocalized with the NPY-IR puncta. C, Neuroendocrine AtT-20 cell costained for CPE and NPY. Punctate localization of endogenous (PE immunoreactivity was found in the cell body and the tips of the processes (arrow). Because AtT-20 cells do not endogenously synthesize NPY, no staining with an NPY antibody was seen (middle and right). D, AtT-20 cell transfected with NPY prohormone. In this cell, the NPY-IR puncta colocalized with the endogenous (PE-IR puncta. Scale bar, $15 \mu \mathrm{m}$.

Analysis. To quantify NPY secretion, images were taken of cells at random on each coverslip (i.e., each experimental treatment). The same acquisition times were used for all cells in a particular experiment. To quantify secretion, the number of NPY-IR puncta per cell was counted. For each experiment, an intensity threshold that identified visually unambiguous puncta was determined after examining several coverslips. The threshold value was subsequently used to analyze all coverslips from that experiment. Typically, the area around the nucleus was omitted from analysis. Values were then expressed relative to the number of puncta in the positive control cells. For measurements of fluorescence ratios (see Fig. 4C), equal numbers of puncta were picked in each channel using the same size area of interest. Statistical significance was assessed using ANOVA and the Tukey's post hoc comparisons test. Image-Pro Plus 5.1 (Media Cybernetics), OriginPro7, and Excel were used for data analysis.

Measurement of intracellular $\mathrm{Ca}^{2+}$ levels. Astrocytes (8-11 DAP) were incubated in extracellular solution containing $2.5 \mu \mathrm{M}$ fura-2 AM plus $0.05 \%$ Pluronic F-127 for $60 \mathrm{~min}$ at $37^{\circ} \mathrm{C}$. After incubation, the cells were washed with extracellular solution and imaged using a Nikon E600 FN microscope and a $40 \times$ water-immersion objective. Cells were sequentially illuminated at 340 and $380 \mathrm{~nm}$ for $100 \mathrm{~ms}$ every $2 \mathrm{~s}$, and emission was collected at $510 \mathrm{~nm}$ using a Photometrics Cascade 512B camera
(Roper Scientific) and InVivo software (Media Cybernetics). Statistical significance was assessed using ANOVA.

Transfection and live cell imaging experiments. Astrocytes were plated onto coverslips and transfected $48 \mathrm{~h}$ later with $1 \mu \mathrm{g}$ of pNPY.Fa and $0.25 \mu \mathrm{g}$ of pGFP using $1.5 \mu \mathrm{l}$ of Lipofectamine 2000 (Invitrogen) per coverslip. AtT-20 cells were transfected with $0.65 \mu \mathrm{g}$ of pNPY.Fa and $0.2 \mu \mathrm{g}$ of pGFP using $3 \mu$ l of Lipofectamine 2000 per coverslip. Cells were stained $2 \mathrm{~d}$ later. The pNPY.Fa plasmid, which encodes the NPY prohormone tagged with FMRFamide, has been described previously (Whim and Moss, 2001). Expression of this plasmid results in the cosynthesis of NPY and FMRFamide because they are contained on the same prohormone. The pNPY-RFP plasmid was constructed by fusing mRFP1 (provided by R. Y. Tsien, University of California San Diego, La Jolla, CA) to the COOH end of NPY [i.e., upstream of the KR consensus cleavage site, thus preventing removal of the red fluorescent protein (RFP) tag in the lumen of the dense-core granules]. A stop codon was inserted after RFP (to avoid synthesis of FMRFamide). All constructs were verified by sequencing.

For live cell imaging experiments, astrocytes were plated in glass-bottomed dishes. Cells were cotransfected after $48 \mathrm{~h}$ with $3 \mu \mathrm{g}$ of pNPY-RFP and $0.5 \mu \mathrm{g}$ of pGFP using calcium phosphate (Jiang et al., 2004) and used 2-3 d after transfection. During an imaging experiment, the dish was mounted on the microscope in a semienclosed superfusion chamber to prevent fluctuations in bath volume.

\section{Results}

A population of cortical astrocytes synthesizes NPY

In neuron-astrocyte cocultures, both cell types unexpectedly showed prominent NPY immunoreactivity (Fig. $1 A$ ). To examine the expression in more detail, purified cortical astrocyte cultures were costained for NPY and GFAP, a marker of type I and II astrocytes (Raff et al., 1983). NPY-IR puncta were found in both GFAP-positive and -negative cells as early as $4 \mathrm{DAP}$ and continued to increase in prominence up to 12 DAP (Fig. $1 B$ ) (at 12 DAP, $72 \pm 3 \%$ of the GFAP-IR cells were also NPY immunoreactive; mean $\pm \mathrm{SD} ; n=3$ separate experiments, 29-34 cells per experiment). NPY-IR astrocytes were widely distributed because similar staining was found in GFAP-IR cells isolated from the hippocampus, hypothalamus, and cerebellum (data not shown). Staining was found using two different NPY antibodies (see Materials and Methods) and was blocked by preabsorption with $100 \mu \mathrm{M}$ NPY but not with metenkephalin (data not shown), a peptide that is also synthesized by some astrocytes (Hauser et al., 1990). Omission of the primary NPY antibody eliminated the staining (Fig. $1 B$, insets). NPY-IR astrocytes were also found in situ when thin slices were prepared from the CNS (Fig. 1C), suggesting that NPY is present in these cells under physiological conditions. We then used MALDI-TOF mass spectrometry to determine whether astrocytes contained NPY. In the astrocyte lysate, we identified a peak with an $\mathrm{m} / \mathrm{z}$ value corresponding to that of authentic NPY (Fig. $1 D, E$ ). Fi- 

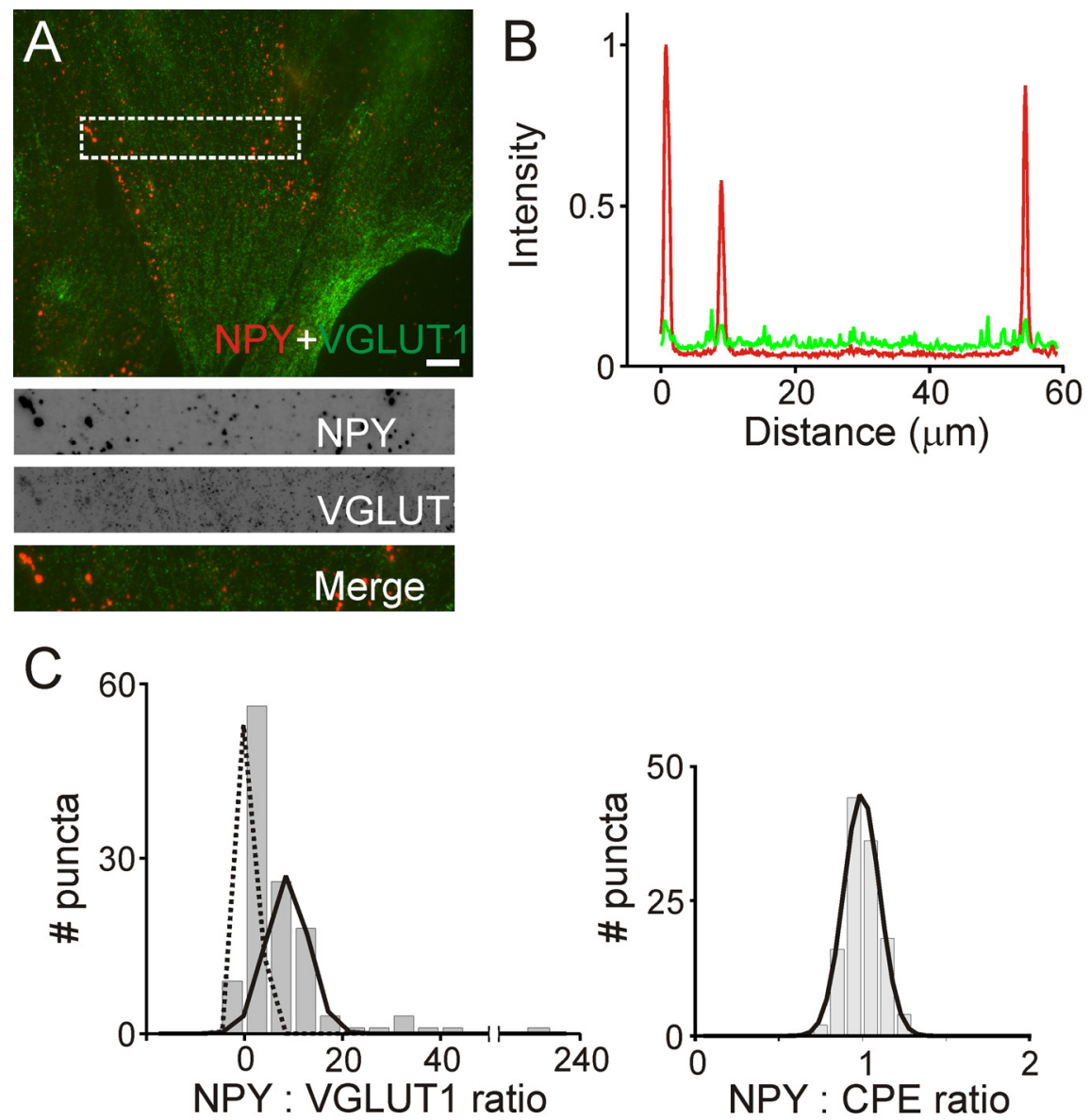

Figure 4. Synaptic-like vesicles and NPY puncta are differentially distributed. $A$, Example of an astrocyte that was stained for VGLUT1 and NPY. The bottom three panels show the boxed region in the top panel. VGLUT1-IR puncta are smaller than the NPY-IR puncta and do not colocalize. NPY and VGLUT1 fluorescence images are shown in grayscale and inverted to emphasize the punctate staining. Scale bar, $10 \mu \mathrm{m}$. $\boldsymbol{B}$, Line scan through the center of the boxed region in $\boldsymbol{A}$. Intensity values were normalized to the peak of the NPY immunoreactivity. $C$, Ratio of the NPY and VGLUT1 immunoreactivity in individual puncta has a biphasic relationship $\left(R^{2}=0.99 ; n=120\right.$ puncta from 3 cells $)$, confirming the presence of two populations of puncta. For comparison, the distribution of NPY and CPE immunoreactivity in individual puncta (Fig. 3B) has a single peak $\left(R^{2}=0.99 ; n=120\right.$ puncta from 3 cells). The best-fit Gaussian distributions are shown overlaid on the data.

nally, when mRNA was extracted from purified glial cultures and used in a reverse transcription-PCR (RT-PCR), amplicons of the expected size and sequence for NPY and GFAP were produced (Fig. $1 F$ ), indicating the presence of mRNAs encoding NPY and GFAP. Thus, several lines of evidence are consistent with the synthesis and expression of NPY in cortical astrocytes. This is in agreement with other work reporting the presence of NPY immunoreactivity and NPY mRNA in human and rodent astrocytes (Barnea et al., 1998, 2001).

\section{Astrocytes contain the synthetic pathway(s) required for neuropeptide synthesis}

If astrocytes endogenously contain NPY, they should have the metabolic pathway(s) required for neuropeptide production. To test this idea, we examined whether astrocytes could synthesize a foreign neuropeptide. Cultures were transfected with a plasmid encoding the NPY prohormone that had been tagged with FMRFamide (Whim and Moss, 2001) and a plasmid encoding green fluorescent protein (GFP; to identify the transfected cells). This should result in the expression of both NPY and FMRFamide, a small neuropeptide that has not been found endogenously in the mammalian nervous system (Zajac and Mollereau, 2006).
Whereas control cells showed no FMRFamide immunoreactivity, GFP-positive cells contained FMRFamide-IR puncta (Fig. 2). Thus, cortical astrocytes are able to synthesize a foreign neuropeptide when transfected with the appropriate cDNA.

NPY immunoreactivity colocalizes with the dense-core granule synthetic pathway

Synthesis of neuropeptides in neurons and neuroendocrine cells occurs via a well defined pathway that involves the endoplasmic reticulum (ER) and Golgi network (Sossin et al., 1989). Ultimately, the peptides reside in dense-core granules that can fuse with the cell membrane (Whim, 2006). If astrocytes make neuropeptide transmitters, they are expected to be associated with the ER-Golgi pathway. Astrocytes were therefore stained for GM130, a marker of the cis-Golgi (Nakamura et al., 1995). GM130 immunoreactivity was extensive and seen particularly in a perinuclear region. NPY immunoreactivity was colocalized in the same area of the cell (Fig. $3 A$ ). Thus, the NPY immunoreactivity is appropriately located for a molecule that passes through the regulated secretory pathway.

Cells were also examined for the expression of CPE. This enzyme is located in dense-core granules and is involved in the processing of many neuropeptide prohormones (Fricker, 1988). CPE immunoreactivity in astrocytes was punctate (Fig. $3 B$ ), consistent with a marker of dense granules. Costaining for CPE and NPY indicated a substantial overlap (Fig. $3 B$ ). The intensity ratio of the NPY and CPE immunoreactivity in individual puncta showed a single Gaussian distribution indicating that all NPY-IR granules contained CPE immunoreactivity (Fig. 4C). To confirm that the punctate CPE immunoreactivity arose from the labeling of densecore granules, AtT-20 cells were stained with the CPE antibody. These neuroendocrine cells do not produce endogenous NPY but have dense-core granules that contain peptides (Dickerson et al., 1987). Punctate CPE immunoreactivity was concentrated in the tips of the processes (Fig. 3C), the site of peptide accumulation in these cells (Tooze and Burke, 1987). Although control cells did not stain for NPY (Fig. 3C), NPY- and CPE-IR puncta were colocalized in cells that had been transfected with the NPY plasmid (Fig. 3D). This is expected if both antibodies recognized antigens that are located in dense-core granules.

Thus, cortical astrocytes can synthesize both endogenous and foreign neuropeptides. Furthermore, an endogenous neuropeptide, NPY, colocalizes with GM130 and CPE, two independent markers of the dense-core granule synthetic pathway.

\section{NPY-containing granules and synaptic-like vesicles are differentially distributed in astrocytes}

In neurons, classical and peptide cotransmitters are located in vesicles and dense-core granules, respectively (Kupfermann, 
1991). These organelles are typically found in different regions of the cell; vesicles are clustered at the active zone, whereas peptide-containing dense-core granules are diffusively distributed in the axon or dendrite (Pickel et al., 1995; Hartmann et al., 2001). Astrocytes also contain small synaptic-like vesicles that are involved in the secretion of glutamate (Bezzi et al., 2004; Montana et al., 2004). To examine the astrocytic distribution of synaptic-like vesicles and peptide-containing granules, cells were stained for VGLUT1, the vesicular glutamate transporter. As described previously (Montana et al., 2004; Anlauf and Derouiche, 2005), some astrocytes had punctate VGLUT1 staining, and this was typically distributed throughout the cell. Some of the VGLUT1-IR cells also stained for NPY (Fig. 4A). However, the VGLUT1- and NPY-IR puncta were not colocalized, and the former were smaller than the NPY-IR puncta (Fig. $4 A$, bottom panels). A fluorescence profile through the center of a cell showed that the VGLUT1 immunoreactivity was also more uniformly distributed (Fig. 4B). An intensity-distribution plot of the NPY and VGLUT1 immunoreactivity was bimodal, confirming the presence of two organelle populations. As a control, a similar analysis of NPY immunoreactivity/CPE immunoreactivity revealed a single population of granules (Fig. $4 C$; see also Fig. $3 B$ ).

Thus, in both neurons and astrocytes, small molecule and peptide transmitters are contained in distinct organelles. However, in contrast to neurons, there is no obvious clustering of these organelles at putative release sites.

\section{Stimulation-dependent NPY secretion from astrocytes}

If the NPY-IR puncta do contain an authentic transmitter, a signaling pathway(s) presumably exists that regulates peptide secretion. To test this idea, we challenged cells for 1 min with glutamate, ATP, histamine, or bradykinin. These native agonists can evoke the secretion of various molecules from astrocytes (Lipnik-Stangelj and Carman-Krzan, 2004; Montana et al., 2004; Mothet et al., 2005). After stimulation, the cells were rapidly fixed and stained for NPY. We reasoned that if secre-

tion did occur, then NPY-IR puncta would become visible on the surface of the cell. Because no permeabilization step was included, any staining should be limited to exposed, extracellular NPY. This strategy has revealed secretion in a variety of other preparations including chromaffin cells and pituitary lactotrophs (Phillips et al., 1983; Angleson et al., 1999).

After treatment with the secretagogues, NPY-IR puncta did
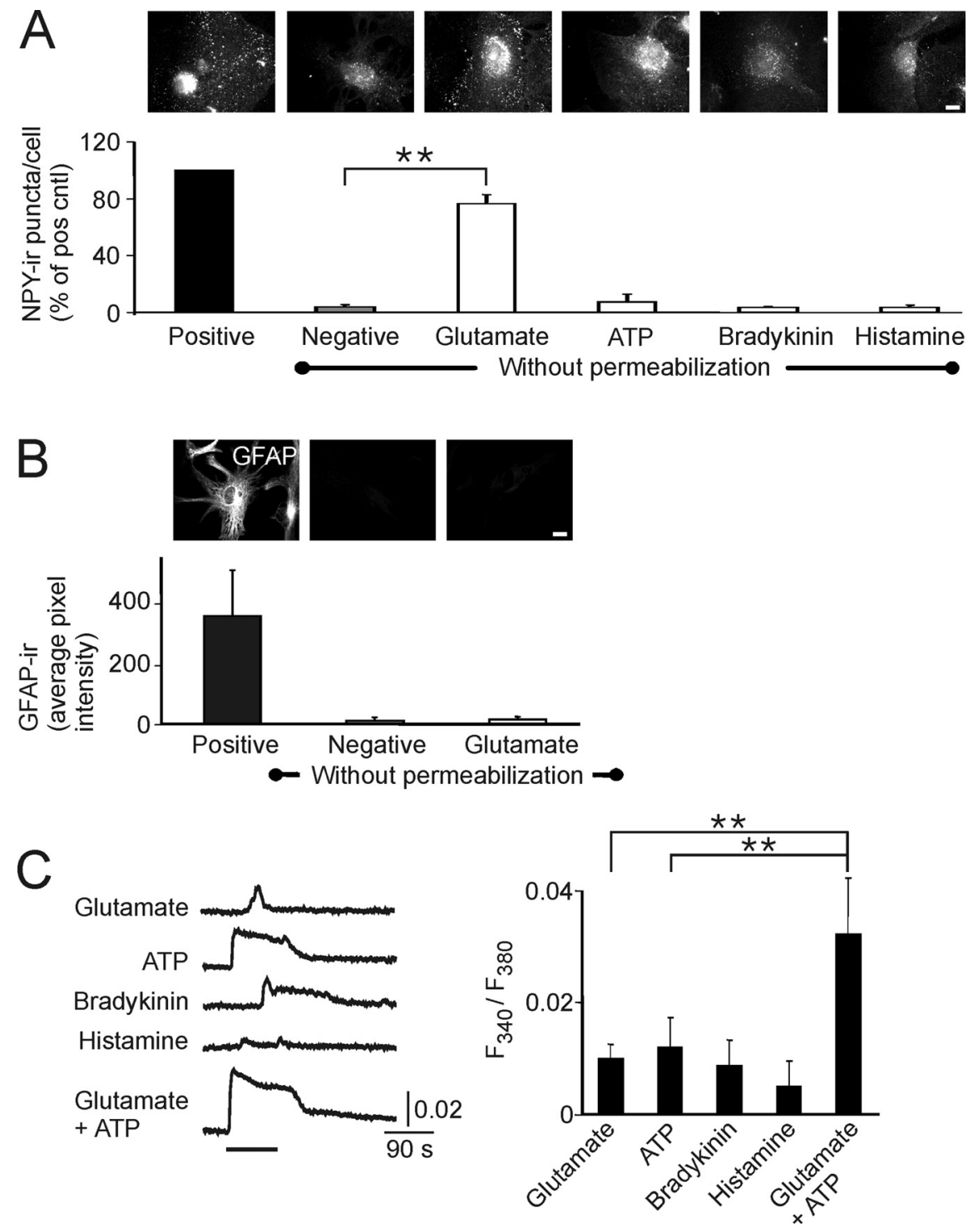

Figure 5. Stimulation-dependent trafficking of NPY-IR puncta. $\boldsymbol{A}$, Astrocytes were incubated in a variety of agonists (1 mM glutamate, $10 \mu \mathrm{m}$ ATP, $100 \mathrm{~nm}$ bradykinin, and $1 \mu \mathrm{m}$ histamine) for $1 \mathrm{~min}$, fixed, and stained for NPY. Each image (top) is a representative cell from each treatment. Positive, Intracellular NPY-IR; Negative, surface NPY-IR. Only the cells in the positive control (pos cntl) were permeabilized after fixation (to reveal intracellular NPY staining). All other cells were stained in the absence of permeabilization to assess surface NPY immunoreactivity. Group data (bottom) indicate that incubation in glutamate resulted in a significant increase in surface punctate NPY immunoreactivity compared with the negative control (surface staining in the absence of agonist). Values are mean \pm SD; $n=3$ separate experiments, $7-13$ cells per treatment in each experiment. ${ }^{* *} p<$ 0.01. B, Fixation does not functionally permeabilize the astrocytic membrane. Examples of astrocytes (top) stained for GFAP (an intracellular protein) are shown. Positive, Intracellular GFAP immunoreactivity (cell permeabilized after fixation); Negative, surface GFAP immunoreactivity (no permeabilization); Glutamate, cell incubated in $1 \mathrm{~mm}$ glutamate for 1 min and stained for GFAP without permeabilization. Group data (bottom) indicate that glutamate stimulation did not result in an increase in surface GFAP immunoreactivity. Thus, in the absence of permeabilization, the antibody cannot access intracellular antigens, and this is not altered by the presence of glutamate. Values are mean \pm SD; $n=2$ separate experiments, $8-10$ cells per treatment in total. $C$, Examples of agonist-evoked changes in intracellular [Ca] in astrocytes monitored using fura-2. Group data (right) show that $1 \mathrm{~mm}$ glutamate, $10 \mu \mathrm{m}$ ATP, $100 \mathrm{~nm}$ bradykinin, and $1 \mu \mathrm{m}$ histamine all elevate $[\mathrm{Ca}]_{\mathrm{i}}$. The combined response to glutamate plus ATP is significantly greater than to either agonist alone. Values are mean \pm SD; $n=3$ separate experiments, $8-15$ cells per treatment in total. ${ }^{* *} p<0.01$. Scale bars, $15 \mu \mathrm{m}$.

appear on the surface of many cells (Fig. 5A). The excitatory transmitter glutamate was a particularly potent secretory stimulus, whereas ATP, bradykinin, and histamine were ineffective. Two control experiments indicated that the staining was attributable to the stimulation-dependent exposure of NPYcontaining granules to the extracellular space. First, in the absence of glutamate and no permeablization, very little membrane 

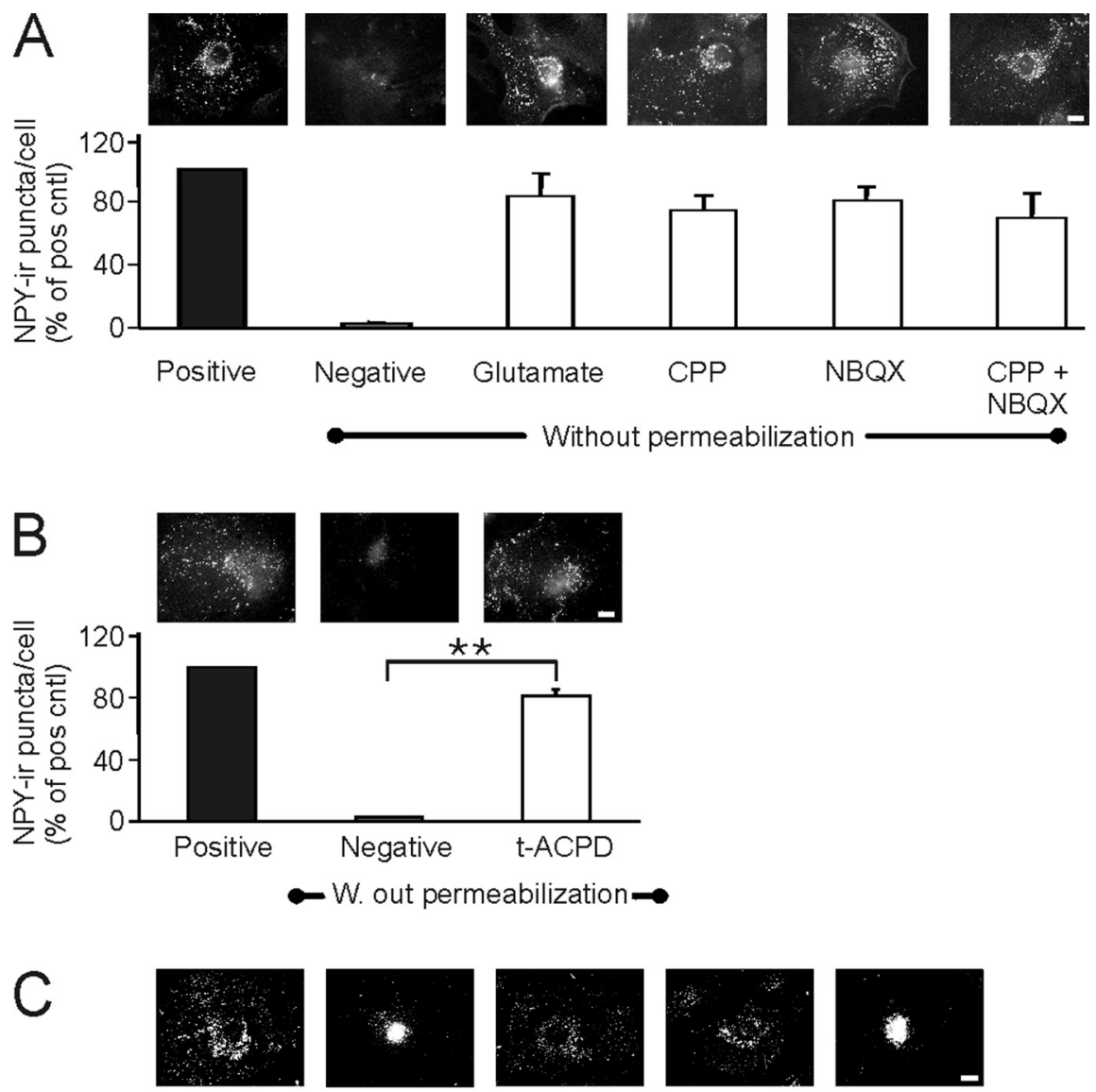

$\star \star$

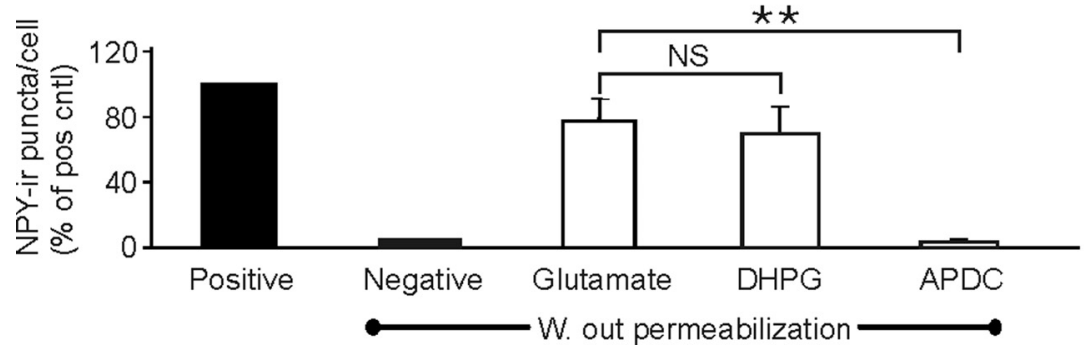

Figure 6. Metabotropic but not ionotropic glutamate receptors evoke the extracellular appearance of NPY-IR puncta. $\boldsymbol{A}$, Examples of astrocytes (top) treated with glutamate and ionotropic glutamate receptor antagonists ( $1 \mathrm{~mm}$ glutamate, $10 \mu \mathrm{M} \mathrm{CPP,}$ $10 \mu \mathrm{m} \mathrm{NBQX).} \mathrm{Cells} \mathrm{were} \mathrm{incubated} \mathrm{with} \mathrm{antagonists} \mathrm{or} \mathrm{vehicle} \mathrm{for} 10 \mathrm{~min}$ before glutamate stimulation, fixed, and stained for NPY without permeabilization (except for the positive control that reveals intracellular NPY immunoreactivity). Group data (bottom) indicate that an antagonist of AMPA receptors (CPP), NMDA receptors (NBQX), or their combined application did not alter the glutamate-induced appearance of NPY-IR puncta. Values are mean $\pm S D ; n=3$ separate experiments, $8-11$ cells per treatment in each experiment. $\boldsymbol{B}$, Same as above, except that astrocytes were treated for 1 min with $100 \mu \mathrm{m} \mathrm{t}$-ACPD, an agonist of metabotropic glutamate receptors. Group data (bottom) indicate that activation of metabotropic glutamate receptors produced a significant increase in the surface appearance of NPY-IR puncta. Values are mean $\pm S D ; n=3$ separate experiments, $8-10$ cells per treatment in each experiment. C, Examples of astrocytes treated for $1 \mathrm{~min}$ with agonists of group I and II metabotropic glutamate receptors ( $1 \mathrm{~mm}$ glutamate, $10 \mu \mathrm{m} \mathrm{DHPG}$, and $10 \mu \mathrm{m} \mathrm{APCD}$ ). Group data (bottom) show that activation of group I metabotropic glutamate receptors with DHPG induced the appearance of NPY-IR puncta. APDC, a group II agonist, was ineffective. Values are mean $\pm S D ; n=3$ separate experiments, $8-11$ cells per treatment in each experiment. ${ }^{* *} p<0.01$. Scale bars, $15 \mu \mathrm{m}$. pos cntl, Positive control.

staining was observed (a negative control) (Fig. 5A). However, significant intracellular staining was seen in permeabilized sister cultures (a positive control) (Fig. 5A). Second, we tested whether fixation alone led to membrane permeabilization. Fixed cells were stained for GFAP, an intracellular protein that should not become exposed to the extracellular medium. Under these conditions, very little immunoreactivity was observed (Fig. 5B). Importantly, this staining was not different in cells that had been exposed to glutamate.
Thus, the puncta seen in the nonpermeabilized astrocytes after glutamate stimulation appear to be caused by NPYcontaining granules that have fused with the cell membrane.

Several agonists elevate intracellular $\mathrm{Ca}^{2+}$ but vary in their ability to cause NPY secretion

The observation that glutamate, but not ATP, bradykinin, or histamine, caused detectable fusion of NPY-IR puncta was unexpected because all have been used as secretagogues in astrocytes. Because NPY secretion requires elevation of intracellular calcium (see Fig. 7A), we examined the relative ability of these agonists to alter cytoplasmic calcium. Each increased $[\mathrm{Ca}]_{\mathrm{i}}$, and there was no significant difference in the peak increase in $[\mathrm{Ca}]_{\mathrm{i}}$ between the different ligands (Fig. 5C). This was not attributable to saturation of the fluorescent signal because cotreatment with ATP and glutamate was significantly greater than either agonist alone (Fig. 5C). Surprisingly, ATP, which did not evoke NPY secretion, gave rise to a sustained elevation of $[\mathrm{Ca}]_{\mathrm{i}}$ that was not seen with glutamate (Fig. $5 A, C)$. Because both ATP and glutamate cause release of classical transmitter from astrocytes but only the latter evokes NPY release (Jeremic et al., 2001; Mothet et al., 2005) (Fig. 5A), this raises the possibility that astrocytes can differentially control peptide and classical transmitter secretion.

Activation of metabotropic glutamate receptors and release of calcium from intracellular stores evokes the surface appearance of NPY-IR puncta

Astrocytes express both ionotropic and metabotropic glutamate receptors (Shelton and McCarthy, 1999; Janssens and Lesage, 2001). To determine which class of receptors was involved, the glutamateinduced translocation of NPY-IR puncta was examined in the presence of 3- $((R)-2$ carboxypiperazin-4-yl)-propyl-1-phosphonic acid (CPP) or 2,3-dioxo-6-nitro-1,2,3,4tetrahydrobenzo[f] quinoxaline-7-sulfonoamide (NBQX), antagonists of NMDA and $\mathrm{AMPA} / \mathrm{kainate}$ receptors, respectively (Fig. 6A). Neither antagonist alone nor their combined application significantly suppressed the response to glutamate. This suggests that metabotropic glutamate receptors(s) may be responsible because astrocytes are known to express group I/II receptors (Petralia et al., 1996; Janssens and Lesage, 2001). Consistent with this idea, trans-ACPD, an agonist of group I/II metabotropic glutamate receptors, evoked an increase in the surface appearance of NPY-IR puncta (Fig. 6B). The response was quantitatively similar to that evoked by glutamate. To determine which class of metabotropic glutamate receptors was involved, 
we applied ( $S$ )-3,5-dihydroxyphenylglycine (DHPG) or $(2 R, 4 R)$-4-aminopyrrolidine-2,4-dicarboxylate (APDC), agonists that are specific for group I and group II metabotropic glutamate receptors, respectively (Swanson et al., 2005). An increase in the number of surface NPY-IR puncta was seen after treatment with DHPG but not with APDC (Fig. 6C). The increase in the number of NPY-IR puncta after DHPG treatment was comparable to that after glutamate (Fig. 6C). These experiments indicate that astrocytes express group I metabotropic glutamate receptors that are coupled to NPY secretion.

Metabotropic glutamate receptors are thought to regulate transmitter release via a number of mechanisms including the release of calcium from intracellular stores and the modulation of membrane calcium channels (Fagni et al., 2000). The pathway that evokes fusion of NPY-IR puncta does not appear to involve the influx of extracellular calcium because the metabotropic glutamate receptor-evoked increase in surface NPY-IR puncta was only slightly suppressed in a calcium-free $2 \mathrm{~mm}$ EGTA extracellular solution (Fig. 7A). However the response to glutamate was markedly reduced in cells that were incubated in BAPTA-AM, a membrane-permeable calcium chelator (Fig. 7A). These results indicate that activation of metabotropic glutamate receptors results in the release of intracellular calcium and the subsequent fusion of NPY-IR granules with the cell membrane.

To confirm a role for intracellular calcium stores in regulating the fusion of NPY-IR granules, cells were incubated in $1 \mu \mathrm{M}$ thapsigargin, a $\mathrm{Ca}^{2+}$ ATPase inhibitor that elevates intracellular calcium levels in astrocytes (Innocenti et al., 2000). Cells were treated with thapsigargin for 15 min with and without glutamate stimulation and stained for NPY. A significant increase in surface NPY-IR puncta was observed in thapsigargintreated cells compared with untreated, negative control cells (Fig. $7 B$ ). Cotreatment of cells with thapsigargin and glutamate did not result in a further increase in the number of NPY-IR puncta compared with thapsigargin treatment alone (Fig. $7 B$ ). Thus, the release of calcium from intracellular stores is able to trigger fusion of NPY-IR granules with the cell membrane.

Loss of surface NPY-IR granules occurs after exocytosis To determine how long the NPY-IR puncta remained on the cell surface, astrocytes were stimulated for $1 \mathrm{~min}$ with glutamate and fixed after varying periods of time (i.e., no perme-

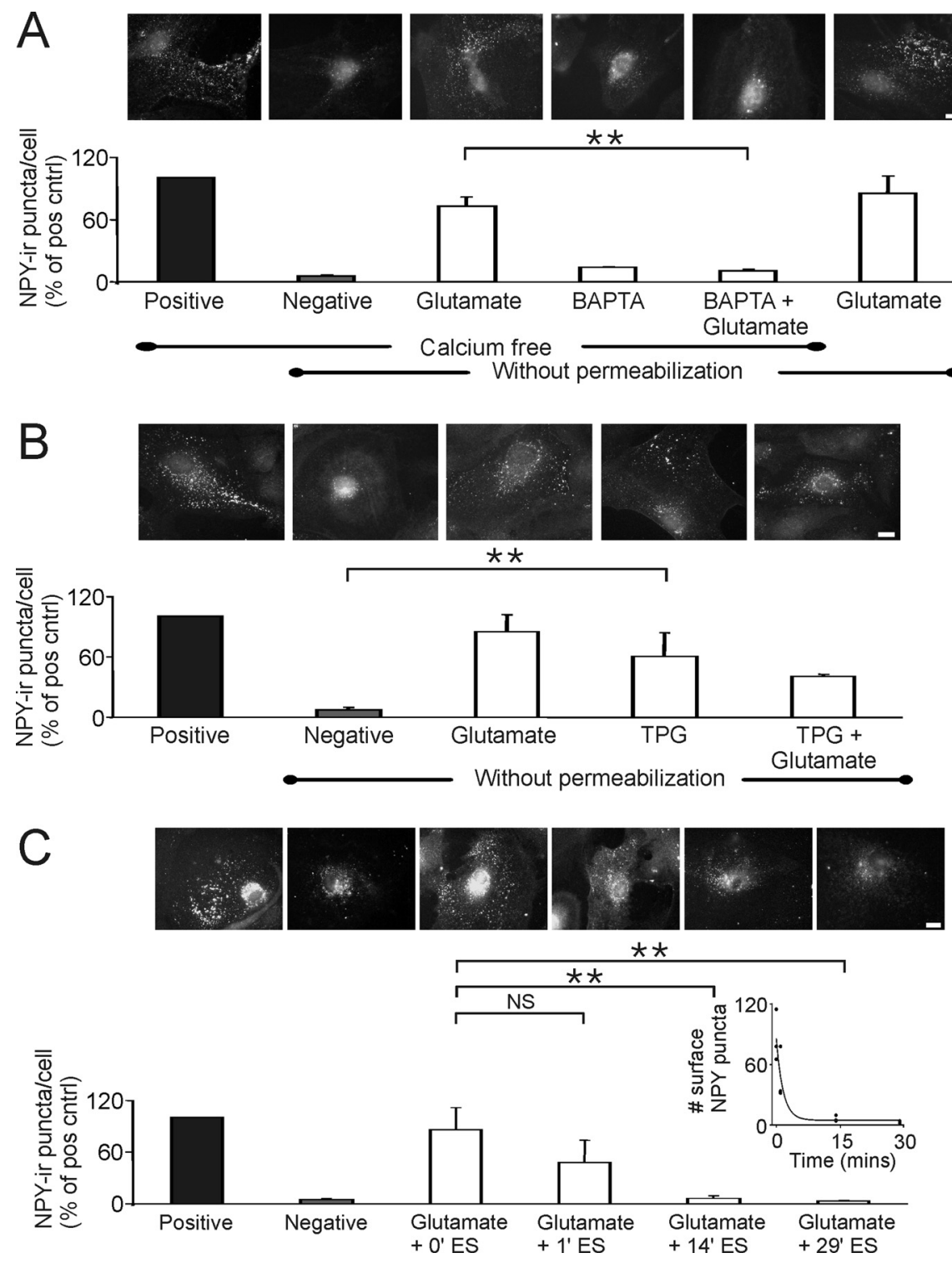

Figure 7. Elevation of intracellular calcium evokes a transient surface appearance of NPY-IR puncta. $\boldsymbol{A}$, Examples of astrocytes (top) treated with $1 \mathrm{~mm}$ glutamate for $1 \mathrm{~min}$ in the presence and absence of $30 \mu \mathrm{M}$ BAPTA-AM (present for 45 min before glutamate stimulation) in a calcium-free medium. Cells were then fixed and stained for NPY without permeabilization (except for the positive control that reveals intracellular NPY immunoreactivity). Group data (bottom) indicate that BAPTA-AM blocked the increase in surface NPY-IR puncta that was triggered by glutamate treatment. Values are mean \pm SD; $n=3$ separate experiments, 10-15 cells per experiment. $\boldsymbol{B}$, Examples of astrocytes (top) treated with $1 \mu \mathrm{m}$ thapsigargin (TPG) for $15 \mathrm{~min}$, in the presence and absence of $1 \mathrm{~mm}$ glutamate for $1 \mathrm{~min}$. Group data (bottom) indicate that thapsigargin, an inhibitor of $\mathrm{Ca}^{2+}$ ATPase, evokes a surface appearance of NPY-IR puncta comparable to that observed by treatment with 1 mm glutamate. Values are mean \pm SD; $n=3$ separate experiments, $10-13$ cells per treatment in each experiment. C, Examples of astrocytes (top) that were stimulated with $1 \mathrm{~mm}$ glutamate for $1 \mathrm{~min}$, fixed, and stained for NPY immunoreactivity after varying lengths of time in extracellular solution (ES). Group data (bottom) show that treatment with glutamate for 1 min (Glutamate $+0^{\prime}$ ES) led to the appearance of surface NPY-IR puncta. A reduction in surface staining occurred within 1 min after removal of the glutamate stimulus (Glutamate $+1^{\prime}$ ES), and control levels of staining were found 14 min later (Glutamate $+14^{\prime}$ ES). Values are mean \pm $\mathrm{SD} ; n=3$ separate experiments, $10-12$ cells per experiment. The inset shows the loss of surface NPY immunoreactivity. Fitting the data with a first-order exponential function revealed a time constant $(\tau)$ of $1.6 \mathrm{~min}$. ${ }^{* *} p<0.01$. Scale bars, $15 \mu \mathrm{m}$. pos cntl, Positive control; NS, not significant.

abilization step). By $1 \mathrm{~min}$ after stimulation, the number of surface NPY-IR puncta had decreased by $45 \%$, and after 14 min the staining was not different from that seen in the control, nonstimulated cells (Fig. 7C). The time constant for the loss of surface staining was 1.6 min (Fig. $7 C$, insets). Thus, substantial loss of surface staining occurs within tens of seconds after termination of the stimulus. 

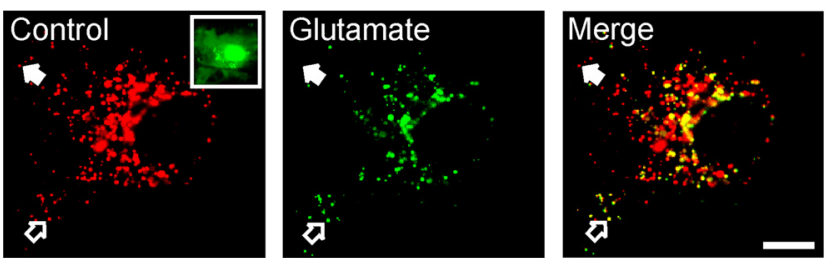

$\mathrm{B}$

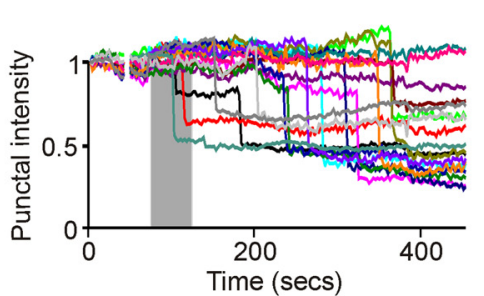

C
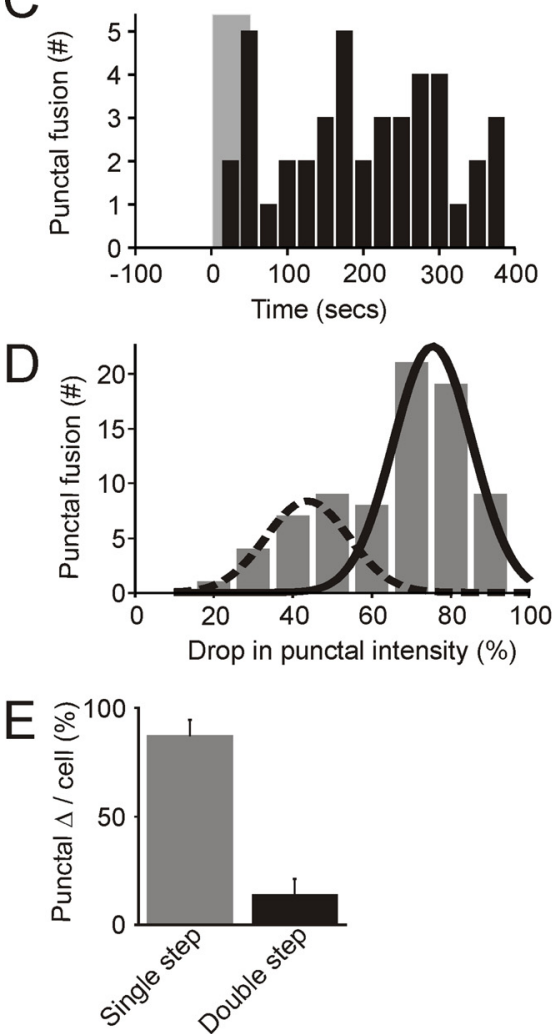

Figure 8. Secretion of NPY monitored by stimulation-dependent loss of NPY-RFP-labeled puncta. $\boldsymbol{A}$, Example of a live astrocyte expressing NPY-RFP. Left, Control image. The inset shows a GFP transfection marker. Middle, After exposure to 1 mm glutamate. Right, Merged image. The filled arrow indicates a punctum (red) that is lost after glutamate treatment. The open arrow indicates a punctum (yellow) that remains after glutamate treatment. Scale bar, $5 \mu \mathrm{m}$. B, Left, Normalized fluorescence of NPY-RFP-containing granules in a cell exposed to $1 \mathrm{~mm}$ glutamate for $50 \mathrm{~s}$ (gray bar). Right, Group data indicate that glutamate treatment results in a significant decrease in the number of NPY-RFP puncta (mean \pm SD; $n=4$ cells; ${ }^{*} p<0.05$ ). C, Time course of NPY-RFP release events from cells exposed to 1 $\mathrm{mm}$ glutamate for $50 \mathrm{~s}$ (gray bar). Left, 0 ccurrence of release events. Right, Same data plotted as the cumulative distribution of release events. Superimposed is a linear fit; $r=0.99$ ( $n=42$ release events from 4 cells). $D$, Left, Distribution of the initial drop in NPY-RFP punctal intensity after exposure to $1 \mathrm{~mm}$ glutamate for $6 \mathrm{~min}(n=78$ release events from 5 cells; superimposed are the best-fit Gaussian distributions; $R^{2}=0.98$ ). Right, Plot of $I_{0}$, the punctal intensity before fusion, versus the drop in $I_{0}$ after fusion $(n=78$ release events from 5 cells). $\boldsymbol{E}$, Quantification of the number of puncta showing a single or double decline in intensity after exposure to 1 mm glutamate for 6 min. Left, Approximately 13\% of puncta show a two (or more) step decline in intensity (mean \pm SD; $n=5$ cells). Right, The mean cumulative decline in punctal intensity is not significantly different between granules that undergo a single or double drop in fluorescent intensity (mean $\pm S D ; n=5$ cells).

\section{Neuropeptide secretion monitored with}

\section{NPY-RFP-labeled granules}

The experiments described so far indicate that astrocytes have NPY-containing dense-core granules that can fuse with the cell membrane. To assess whether peptide release follows granule- cell membrane fusion, astrocytes were transfected with a plasmid encoding NPY fused to RFP. Two days after transfection, many cells had NPY-RFP puncta that were diffusely distributed throughout the cytoplasm (Fig. $8 \mathrm{~A}$ ). By tracking the intensity of multiple puncta in live cells, it was possible to visualize the glutamate-induced release of NPY-RFP. Application of glutamate triggered a reduction in the intensity of individual NPY-RFP puncta in a steplike manner consistent with peptide secretion (Fig. $8 A, B$ ). A $50 \mathrm{~s}$ application of glutamate evoked a significant reduction in the number of NPY-RFP puncta (Fig. $8 B$ ). The same stimulus evoked the extracellular appearance of NPY immunoreactivity (Fig. 5). The glutamate-induced loss of NPY-RFP puncta started during the glutamate application (Fig. $8 C$ ), and a cumulative plot of the release events versus time had a linear relationship. This suggests that once peptide release was triggered, it proceeded at a constant rate (Fig. $8 B$, right).

Quantifying the decline in the fluorescence of individual granules revealed that the percentage decrease in punctal intensity was bimodal. Two Gaussian populations were seen that corresponded to a mean drop in intensity of $\sim 40$ and $75 \%$ (Fig. 8D, left). However, the percentage change in the fluorescence of individual puncta was not related to the initial granule intensity (Fig. $8 D$, right), indicating that this distribution did not arise from dim granules being more difficult to quantify than bright ones. This result suggests that there might be a postfusion regulation of peptide secretion.

Although the fluorescence of the majority of puncta decreased in a single step, in some granules the signal declined in two phases. These "double-step" granules comprised $\sim 13 \%$ of the total release events (Fig. $8 E$, left; for one example, see Fig. $8 B$, black trace). When the cumulative drop in intensity was calculated for these granules, the loss of fluorescence was not different from that seen in "single-step" granules (Fig. $8 E$, right). Thus, on average, both types of events release the same fractional amount of NPY-RFP.

\section{Discussion}

Here we show that cortical astrocytes have the ability to synthesize a range of neuropeptides including both endogenous (NPY) and heterologous (FMRFamide) molecules. These peptides were packaged into dense-core granules that do not fuse constitutively but are part of the regulated secretory pathway. After activation of glutamate receptors, the granules fuse with the cell membrane exposing the peptide- 
containing cores to the extracellular space. Thus astrocytes, like neurons, are able to secrete both classical and peptide neurotransmitters. These results support the emerging consensus that astrocytes are versatile cells that can regulate many aspects of neuronal function (Diamond, 2006).

One important consideration is the physiological relevance of the peptidergic granules. Although the NPY-IR puncta were mainly studied in vitro, NPY-IR astrocytes were also found in situ (albeit at lower levels than in culture). Several lines of evidence indicate that the immunoreactivity arose from NPY in densecore granules. First, the cells contained mRNA encoding NPY, and the MALDI-TOF signal was consistent with authentic NPY. Second, the NPY-IR puncta costained for CPE, an enzyme characteristically found in the large dense-core granules of peptidesynthesizing cells (Fricker, 1988). The NPY immunoreactivity was also partially colocalized with GM130, a Golgi marker. Third, the NPY-IR puncta fused with the cell membrane in a calciumregulated manner and were therefore located within the regulated secretory pathway. Our results are consistent with previous reports showing that rodent and human astrocytes contain the NPY prohormone (Barnea et al., 1998, 2001), secretogranin II, (Calegari et al., 1999), and CPE (Klein et al., 1992). The latter are both markers of the dense-core granule pathway. NPY is therefore a member of a growing list of neuropeptides that have been found in glial cells (Ubink et al., 2003).

In neurons and neuroendocrine cells, the biology of classical and peptide transmitters is distinctive. Peptide transmitters are synthesized as part of larger prohormones and are packaged into dense-core granules. Classical transmitters are found within small synaptic vesicles. The synaptic vesicles are clustered at active zones whereas the peptidergic dense-core granules are more diffusely distributed. Classical transmitters are released by single action potentials, but neuropeptide secretion often requires high-frequency bursts of activity (Dutton and Dyball, 1979; Whim and Lloyd, 1989). Finally, the calcium signals that elicit the release of the two types of transmitters may also be different (Kasai et al., 1996; Ohnuma et al., 2001). Some of these features are also found in astrocytes. Such cells have small vesicles containing classical transmitters such as glutamate and ATP, and dense-core granules containing peptides such as NPY, enkephalins, secretogranin II, and perhaps ATP (Melner et al., 1990; Parpura et al., 1994; Barnea et al., 1998; Calegari et al., 1999; Coco et al., 2003; Bezzi et al., 2004; Panatier et al., 2006). We did not find the marked difference in vesicle and granule clustering that is typical of neurons. As noted by others (Montana et al., 2004), the VGLUT1-positive vesicles were distributed throughout the cell with intense staining occasionally present at the cell membrane. In contrast, granular staining was not found at the cell periphery. Glutamate but not ATP evoked NPY release although both agonists similarly elevated $[\mathrm{Ca}]_{\mathrm{i}}$. Both agonists can elicit the secretion of classical transmitters from astrocytes (Jeremic et al., 2001; Mothet et al., 2005). This suggests that another feature astrocytes may share with neurons is the ability to differentially control the secretion of multiple types of transmitters.

It is curious that astrocytes contain both classical and peptide transmitters. These features were once considered hallmarks of neurons but are apparently shared with astrocytes. Although astrocytes do not generate action potentials, they can release classical transmitters like glutamate via a calcium-dependent fusion mechanism. The underlying molecular mechanism appears similar to that in neurons because it involves the calcium sensor synaptotagmin and various SNARE proteins (Zhang et al., $2004 a, b)$. Although much less is known about the control of pep- tide secretion, a recent study showed that GFP-tagged atrial natriuretic peptide could be released from astrocytes after treatment with a calcium ionophore (Krzan et al., 2003). We found that NPY-containing dense-core granules could fuse with the cell membrane in a stimulation-dependent manner. Of the agonists tested, the activation of endogenous group I metabotropic glutamate receptors was a potent secretory stimulus presumably because it involved the release of calcium from intracellular stores. The release of small molecule transmitters from astrocytes also requires calcium and can be evoked by a variety of agonists including glutamate, ATP, and bradykinin (Parpura et al., 1994; Jeremic et al., 2001; Mothet et al., 2005). Thus, NPY secretion from astrocytes occurs via a regulated secretory pathway and is a calcium-dependent process.

The behavior of the peptidergic granules at a postfusion stage also has similarities to other cell types. In particular, during exocytosis, the peptide-containing dense cores could be bound by extracellular NPY antibody. Prolactin-containing granules in lactrotrophs also remain exposed for extended periods of time (Angleson et al., 1999). Dense-core granules in chromaffin cells contain dopamine $\beta$-hydroxylase $(\mathrm{D} \beta \mathrm{H})$, and secretion results in the appearance of $\mathrm{D} \beta \mathrm{H}$-IR puncta on the cell surface that are subsequently internalized (Phillips et al., 1983; Wick et al., 1997). After secretion in chromaffin cells, GFP-tagged NPY granule cores can be "displayed" on the cell surface for minutes (Perrais et al., 2004). We found that secretion from astrocytes could be followed by monitoring the appearance of NPY-IR puncta on the cell surface, suggesting that these features are not limited to neuroendocrine cells. The NPY immunoreactivity probably arose from a completely exposed granular core because the dimensions of a typical antibody [ $\mathrm{F}_{\mathrm{ab}},>10 \mathrm{~nm}$ (Sarma et al., 1971)] make it unlikely that it could enter through a fusion pore [thought to be $<3 \mathrm{~nm}$ for large dense-core granules (Albillos et al., 1997)].

The live cell imaging experiments reported a decline in the number of NPY-RFP-labeled puncta after glutamate stimulation. This indicates that the fusion of peptidergic granules with the cell membrane leads to peptide secretion. The double-step change in the fluorescence of some granules suggests that peptide release can be regulated at a postfusion step. Such a behavior would be consistent with a repetitive opening and closing of the fusion pore (Henkel et al., 2000). Could NPY release be via a kiss-and-run-type process? Intriguingly, kiss-and-run secretory events have been described in astrocytes that have been loaded with dopamine or FM1-43 (Chen et al., 2005). However, because these organelles stained for the small transmitter glutamate (Chen et al., 2005), they are unlikely to be the peptidergic granules that we have studied. Quantal peptide secretion also has a number of characteristics that probably eliminate a kiss-and-run mode of secretion. Several studies have measured secretion from dense-core granules using a combination of capacitance tracking and fluorescently tagged molecules (Barg et al., 2002; Vardjan et al., 2007). These approaches have indicated that a molecule the size of NPY-RFP is unlikely to exit through a fusion pore. Instead, peptide release probably occurs after full granule fusion (Perrais et al., 2004; Fulop et al., 2005). One possibility is that the double-step signals arise from a compound fusion of granules such as observed between peptidergic granules in lactotrophs (Cochilla et al., 2000). Less likely would be a multiquantal dissolution of the peptide core. We also cannot exclude the possibility that they are caused by the sequential fusion of two granules that are close together.

What could be the function of the astrocytic NPY? As shown for other gliotransmitters (Araque et al., 1998; Kang et al., 1998), 
NPY could regulate transmitter release from nearby neurons. Presynaptic Y2 receptors on Schaffer collaterals (the axons of CA3 neurons) inhibit glutamate release (McQuiston and Colmers, 1996), and NPY can also regulate neuronal excitability via postsynaptic Y receptors (Obrietan and van den Pol, 1996).

Other potential roles for NPY include trophic actions. NPY can regulate the growth of vascular tissue (Zukowska-Grojec et al., 1993) and is a neuroproliferative factor in the CNS (Hansel et al., 2001). Astrocytes produce a variety of trophic factors such as BDNF and NGF, the synthesis of which is increased after cellular trauma (Rudge et al., 1995; Krenz and Weaver, 2000). The levels of hippocampal neuronal NPY mRNA are also elevated after epileptic seizures (Marksteiner et al., 1990; Ma et al., 2002), and NPY can play a protective role (Baraban et al., 1997; Tu et al., 2005). Conceivably, the secretion of NPY from astrocytes during seizure activity could be a protective response that reduces pathological neuronal activity. In fact, dynamic changes in the levels of a variety of astrocytic proteins have been reported including the neuropeptides nociceptin/orphanin FQ, which are synthesized in response to oxidative stress (Rosenberger et al., 2001).

Finally, one additional site of action could be the astrocytes themselves. Some astrocytes express NPY receptors (St-Pierre et al., 2000), raising the possibility of an autocrine site of action.

In conclusion, this work shows that cortical astrocytes have the ability to synthesize a variety of neuropeptides including NPY. The newly produced peptide enters the regulated secretory pathway and is stored in dense-core granules. A secretory stimulus can trigger the fusion of the granules with the cell membrane, resulting in the liberation of peptide to the extracellular space. The results support the idea that astrocytes have two regulatory secretory pathways (mediating classical and peptide transmitter release) and that these cells should be regarded as a potential source of neuropeptides within the mammalian brain.

\section{References}

Albillos A, Dernick G, Horstmann H, Almers W, Alvarez de Toledo G, Lindau M (1997) The exocytotic event in chromaffin cells revealed by patch amperometry. Nature 389:509-512.

Angleson JK, Cochilla AJ, Kilic G, Nussinovitch I, Betz WJ (1999) Regulation of dense core release from neuroendocrine cells revealed by imaging single exocytic events. Nat Neurosci 2:440-446.

Anlauf E, Derouiche A (2005) Astrocytic exocytosis vesicles and glutamate: a high-resolution immunofluorescence study. Glia 49:96-106.

Araque A, Sanzgiri RP, Parpura V, Haydon PG (1998) Calcium elevation in astrocytes causes an NMDA receptor-dependent increase in the frequency of miniature synaptic currents in cultured hippocampal neurons. J Neurosci 18:6822-6829.

Baraban SC, Hollopeter G, Erickson JC, Schwartzkroin PA, Palmiter RD (1997) Knock-out mice reveal a critical antiepileptic role for neuropeptide Y. J Neurosci 17:8927-8936.

Barg S, Olofsson CS, Schriever-Abeln J, Wendt A, Gebre-Medhin S, Renstrom E, Rorsman P (2002) Delay between fusion pore opening and peptide release from large dense-core vesicles in neuroendocrine cells. Neuron 33:287-299.

Barnea A, Aguila-Mansilla N, Bigio EH, Worby C, Roberts J (1998) Evidence for regulated expression of neuropeptide $\mathrm{Y}$ gene by rat and human cultured astrocytes. Regul Pept 75- 76:293-300.

Barnea A, Roberts J, Keller P, Word RA (2001) Interleukin-1beta induces expression of neuropeptide $\mathrm{Y}$ in primary astrocyte cultures in a cytokinespecific manner: induction in human but not rat astrocytes. Brain Res 896:137-145.

Bergles DE, Dzubay JA, Jahr CE (1997) Glutamate transporter currents in Bergmann glial cells follow the time course of extrasynaptic glutamate. Proc Natl Acad Sci U S A 94:14821-14825.

Bezzi P, Gundersen V, Galbete JL, Seifert G, Steinhauser C, Pilati E, Volterra A (2004) Astrocytes contain a vesicular compartment that is competent for regulated exocytosis of glutamate. Nat Neurosci 7:613-620.
Buzas B, Rosenberger J, Cox BM (1998) Activity and cyclic AMP-dependent regulation of nociceptin/orphanin FQ gene expression in primary neuronal and astrocyte cultures. J Neurochem 71:556-563.

Calegari F, Coco S, Taverna E, Bassetti M, Verderio C, Corradi N, Matteoli M, Rosa P (1999) A regulated secretory pathway in cultured hippocampal astrocytes. J Biol Chem 274:22539-22547.

Che FY, Yuan Q, Kalinina E, Fricker LD (2004) Examination of the rate of peptide biosynthesis in neuroendocrine cell lines using a stable isotopic label and mass spectrometry. J Neurochem 90:585-594.

Chen X, Wang L, Zhou Y, Zheng LH, Zhou Z (2005) “Kiss-and-run” glutamate secretion in cultured and freshly isolated rat hippocampal astrocytes. J Neurosci 25:9236-9243.

Cochilla AJ, Angleson JK, Betz WJ (2000) Differential regulation of granuleto-granule and granule-to-plasma membrane fusion during secretion from rat pituitary lactotrophs. J Cell Biol 150:839-848.

Coco S, Calegari F, Pravettoni E, Pozzi D, Taverna E, Rosa P, Matteoli M, Verderio C (2003) Storage and release of ATP from astrocytes in culture. J Biol Chem 278:1354-1362.

Diamond JS (2006) Astrocytes put down the broom and pick up the baton. Cell 125:639-641.

Dickerson IM, Dixon JE, Mains RE (1987) Transfected human neuropeptide Y cDNA expression in mouse pituitary cells. Inducible high expression, peptide characterization, and secretion. J Biol Chem 262:13646-13653.

Dumont Y, Chabot JG, Quirion R (2004) Receptor autoradiography as mean to explore the possible functional relevance of neuropeptides: focus on new agonists and antagonists to study natriuretic peptides, neuropeptide $\mathrm{Y}$ and calcitonin gene-related peptides. Peptides 25:365-391.

Dutton A, Dyball RE (1979) Phasic firing enhances vasopressin release from the rat neurohypophysis. J Physiol 290:433-440.

Evanko DS, Zhang Q, Zorec R, Haydon PG (2004) Defining pathways of loss and secretion of chemical messengers from astrocytes. Glia 47:233-240.

Fagni L, Chavis P, Ango F, Bockaert J (2000) Complex interactions between mGluRs, intracellular $\mathrm{Ca} 2+$ stores and ion channels in neurons. Trends Neurosci 23:80-88.

Fann MJ, Patterson PH (1993) A novel approach to screen for cytokine effects on neuronal gene expression. J Neurochem 61:1349-1355.

Fellin T, Pascual O, Gobbo S, Pozzan T, Haydon PG, Carmignoto G (2004) Neuronal synchrony mediated by astrocytic glutamate through activation of extrasynaptic NMDA receptors. Neuron 43:729-743.

Fricker LD (1988) Carboxypeptidase E. Annu Rev Physiol 50:309-321.

Fulop T, Radabaugh S, Smith C (2005) Activity-dependent differential transmitter release in mouse adrenal chromaffin cells. J Neurosci 25:7324-7332.

Grandes P, Kq K, Morino P, Cuenod M, Streit P (1991) Homocysteate, an excitatory transmitter candidate localized in glia. Eur J Neurosci 3:1370-1373.

Gray TS, Morley JE (1986) Neuropeptide Y: anatomical distribution and possible function in mammalian nervous system. Life Sci 38:389-401.

Hansel DE, Eipper BA, Ronnett GV (2001) Neuropeptide Y functions as a neuroproliferative factor. Nature 410:940-944.

Hartmann M, Heumann R, Lessmann V (2001) Synaptic secretion of BDNF after high-frequency stimulation of glutamatergic synapses. EMBO J 20:5887-5897.

Hauser KF, Osborne JG, Stiene-Martin A, Melner MH (1990) Cellular localization of proenkephalin mRNA and enkephalin peptide products in cultured astrocytes. Brain Res 522:347-353.

Haydon PG, Carmignoto G (2006) Astrocyte control of synaptic transmission and neurovascular coupling. Physiol Rev 86:1009-1031.

Henkel AW, Meiri H, Horstmann H, Lindau M, Almers W (2000) Rhythmic opening and closing of vesicles during constitutive exo- and endocytosis in chromaffin cells. EMBO J 19:84-93.

Innocenti B, Parpura V, Haydon PG (2000) Imaging extracellular waves of glutamate during calcium signaling in cultured astrocytes. J Neurosci 20:1800-1808.

Janssens N, Lesage AS (2001) Glutamate receptor subunit expression in primary neuronal and secondary glial cultures. J Neurochem 77:1457-1474.

Jeremic A, Jeftinija K, Stevanovic J, Glavaski A, Jeftinija S (2001) ATP stimulates calcium-dependent glutamate release from cultured astrocytes. J Neurochem 77:664-675. 
Jiang M, Deng L, Chen G (2004) High Ca(2+)-phosphate transfection efficiency enables single neuron gene analysis. Gene Ther 11:1303-1311.

Jinno S, Klausberger T, Marton LF, Dalezios Y, Roberts JD, Fuentealba P, Bushong EA, Henze D, Buzsáki G, Somogyi P (2007) Neuronal diversity in GABAergic long-range projections from the hippocampus. J Neurosci 27:8790-8804.

Kang J, Jiang L, Goldman SA, Nedergaard M (1998) Astrocyte-mediated potentiation of inhibitory synaptic transmission. Nat Neurosci 1:683-692.

Kasai H, Takagi H, Ninomiya Y, Kishimoto T, Ito K, Yoshida A, Yoshioka T, Miyashita Y (1996) Two components of exocytosis and endocytosis in phaeochromocytoma cells studied using caged $\mathrm{Ca} 2+$ compounds. J Physiol 494:53-65.

Klein RS, Das B, Fricker LD (1992) Secretion of carboxypeptidase E from cultured astrocytes and from AtT-20 cells, a neuroendocrine cell line: implications for neuropeptide biosynthesis. J Neurochem 58:2011-2018.

Krenz NR, Weaver LC (2000) Nerve growth factor in glia and inflammatory cells of the injured rat spinal cord. J Neurochem 74:730-739.

Krzan M, Stenovec M, Kreft M, Pangrsic T, Grilc S, Haydon PG, Zorec R (2003) Calcium-dependent exocytosis of atrial natriuretic peptide from astrocytes. J Neurosci 23:1580-1583.

Kupfermann I (1991) Functional studies of cotransmission. Physiol Rev $71: 683-732$.

Lipnik-Stangelj M, Carman-Krzan M (2004) Activation of histamine H1receptor enhances neurotrophic factor secretion from cultured astrocytes. Inflamm Res 53:245-252.

Liu SQ, Cull-Candy SG (2000) Synaptic activity at calcium-permeable AMPA receptors induces a switch in receptor subtype. Nature 405:454-458

Ma XM, Mains RE, Eipper BA (2002) Plasticity in hippocampal peptidergic systems induced by repeated electroconvulsive shock. Neuropsychopharmacology 27:55-71.

Ma Y, Hu H, Berrebi AS, Mathers PH, Agmon A (2006) Distinct subtypes of somatostatin-containing neocortical interneurons revealed in transgenic mice. J Neurosci 26:5069-5082.

Marksteiner J, Ortler M, Bellmann R, Sperk G (1990) Neuropeptide Y biosynthesis is markedly induced in mossy fibers during temporal lobe epilepsy of the rat. Neurosci Lett 112:143-148.

McCarthy KD, de Vellis J (1980) Preparation of separate astroglial and oligodendroglial cell cultures from rat cerebral tissue. J Cell Biol 85:890-902.

McKenzie JC, Berman NE, Thomas CR, Young JK, Compton LY, Cothran LN, Liu WL, Klein RM (1994) Atrial natriuretic peptide-like (ANP-LIR) and ANP prohormone immunoreactive astrocytes and neurons of human cerebral cortex. Glia 12:228-243.

McQuiston AR, Colmers WF (1996) Neuropeptide Y2 receptors inhibit the frequency of spontaneous but not miniature EPSCs in CA3 pyramidal cells of rat hippocampus. J Neurophysiol 76:3159-3168.

Melner MH, Low KG, Allen RG, Nielsen CP, Young SL, Saneto RP (1990) The regulation of proenkephalin expression in a distinct population of glial cells. EMBO J 9:791-796.

Michel JP, Sakamoto N, Bouvier R, Tommasi M, Pearson J (1986) Substance P-immunoreactive astrocytes related to deep white matter and striatal blood vessels in human brain. Brain Res 377:383-387.

Montana V, Ni Y, Sunjara V, Hua X, Parpura V (2004) Vesicular glutamate transporter-dependent glutamate release from astrocytes. J Neurosci 24:2633-2642.

Mothet JP, Pollegioni L, Ouanounou G, Martineau M, Fossier P, Baux G (2005) Glutamate receptor activation triggers a calcium-dependent and SNARE protein-dependent release of the gliotransmitter D-serine. Proc Natl Acad Sci U S A 102:5606-5611.

Nakamura N, Rabouille C, Watson R, Nilsson T, Hui N, Slusarewicz P, Kreis TE, Warren G (1995) Characterization of a cis-Golgi matrix protein, GM130. J Cell Biol 131:1715-1726.

Obrietan K, van den Pol AN (1996) Neuropeptide Y depresses GABAmediated calcium transients in developing suprachiasmatic nucleus neurons: a novel form of calcium long-term depression. J Neurosci 16:3521-3533.

Ohnuma K, Whim MD, Fetter RD, Kaczmarek LK, Zucker RS (2001) Presynaptic target of $\mathrm{Ca} 2+$ action on neuropeptide and acetylcholine release in Aplysia californica. J Physiol 535:647-662.

Panatier A, Theodosis DT, Mothet JP, Touquet B, Pollegioni L, Poulain DA,
Oliet SH (2006) Glia-derived D-serine controls NMDA receptor activity and synaptic memory. Cell 125:775-784.

Parpura V, Basarsky TA, Liu F, Jeftinija K, Jeftinija S, Haydon PG (1994) Glutamate-mediated astrocyte-neuron signalling. Nature 369:744-747.

Parpura V, Liu F, Brethorst S, Jeftinija K, Jeftinija S, Haydon PG (1995) Alpha-latrotoxin stimulates glutamate release from cortical astrocytes in cell culture. FEBS Lett 360:266-270.

Pascual O, Casper KB, Kubera C, Zhang J, Revilla-Sanchez R, Sul JY, Takano H, Moss SJ, McCarthy K, Haydon PG (2005) Astrocytic purinergic signaling coordinates synaptic networks. Science 310:113-116.

Pasti L, Zonta M, Pozzan T, Vicini S, Carmignoto G (2001) Cytosolic calcium oscillations in astrocytes may regulate exocytotic release of glutamate. J Neurosci 21:477-484.

Perrais D, Kleppe IC, Taraska JW, Almers W (2004) Recapture after exocytosis causes differential retention of protein in granules of bovine chromaffin cells. J Physiol 560:413-428.

Petralia RS, Wang YX, Niedzielski AS, Wenthold RJ (1996) The metabotropic glutamate receptors, mGluR2 and mGluR3, show unique postsynaptic, presynaptic and glial localizations. Neuroscience 71:949-976.

Phillips JH, Burridge K, Wilson SP, Kirshner N (1983) Visualization of the exocytosis/endocytosis secretory cycle in cultured adrenal chromaffin cells. J Cell Biol 97:1906-1917.

Pickel VM, Chan J, Veznedaroglu E, Milner TA (1995) Neuropeptide Y and dynorphin-immunoreactive large dense-core vesicles are strategically localized for presynaptic modulation in the hippocampal formation and substantia nigra. Synapse 19:160-169.

Raff MC, Abney ER, Cohen J, Lindsay R, Noble M (1983) Two types of astrocytes in cultures of developing rat white matter: differences in morphology, surface gangliosides, and growth characteristics. J Neurosci 3:1289-1300.

Rosenberger J, Petrovics G, Buzas B (2001) Oxidative stress induces proorphanin FQ and proenkephalin gene expression in astrocytes through p38and ERK-MAP kinases and NF-kappaB. J Neurochem 79:35-44.

Rudge JS, Pasnikowski EM, Holst P, Lindsay RM (1995) Changes in neurotrophic factor expression and receptor activation following exposure of hippocampal neuron/astrocyte cocultures to kainic acid. J Neurosci 15:6856-6867.

Sarma VR, Silverton EW, Davies DR, Terry WD (1971) The threedimensional structure at 6 A resolution of a human gamma Gl immunoglobulin molecule. J Biol Chem 246:3753-3759.

Schell MJ, Molliver ME, Snyder SH (1995) D-serine, an endogenous synaptic modulator: localization to astrocytes and glutamate-stimulated release. Proc Natl Acad Sci U S A 92:3948-3952.

Shelton MK, McCarthy KD (1999) Mature hippocampal astrocytes exhibit functional metabotropic and ionotropic glutamate receptors in situ. Glia 26:1-11.

Shinoda H, Marini AM, Cosi C, Schwartz JP (1989) Brain region and gene specificity of neuropeptide gene expression in cultured astrocytes. Science 245:415-417.

Sossin WS, Fisher JM, Scheller RH (1989) Cellular and molecular biology of neuropeptide processing and packaging. Neuron 2:1407-1417.

St-Pierre JA, Nouel D, Dumont Y, Beaudet A, Quirion R (2000) Subpopulation of cultured hippocampal astrocytes expresses neuropeptide $\mathrm{Y}$ $\mathrm{Y}(1)$ receptors. Glia 30:82-91.

Swanson CJ, Bures M, Johnson MP, Linden AM, Monn JA, Schoepp DD (2005) Metabotropic glutamate receptors as novel targets for anxiety and stress disorders. Nat Rev Drug Discov 4:131-144.

Tooze J, Burke B (1987) Accumulation of adrenocorticotropin secretory granules in the midbody of telophase AtT20 cells: evidence that secretory granules move anterogradely along microtubules. J Cell Biol 104:1047-1057.

Tu B, Timofeeva O, Jiao Y, Nadler JV (2005) Spontaneous release of neuropeptide $\mathrm{Y}$ tonically inhibits recurrent mossy fiber synaptic transmission in epileptic brain. J Neurosci 25:1718-1729.

Ubink R, Calza L, Hokfelt T (2003) "Neuro"-peptides in glia: focus on NPY and galanin. Trends Neurosci 26:604-609.

van den Pol AN, Obrietan K, Chen G, Belousov AB (1996) Neuropeptide Y-mediated long-term depression of excitatory activity in suprachiasmatic nucleus neurons. J Neurosci 16:5883-5895.

Vardjan N, Stenovec M, Jorgacevski J, Kreft M, Zorec R (2007) Subnanometer fusion pores in spontaneous exocytosis of peptidergic vesicles. J Neurosci 27:4737-4746. 
Whim MD (2006) Near simultaneous release of classical and peptide cotransmitters from chromaffin cells. J Neurosci 26:6637-6642.

Whim MD, Lloyd PE (1989) Frequency-dependent release of peptide cotransmitters from identified cholinergic motor neurons in Aplysia. Proc Natl Acad Sci U S A 86:9034-9038.

Whim MD, Moss GW (2001) A novel technique that measures peptide secretion on a millisecond timescale reveals rapid changes in release. Neuron 30:37-50.

Wick PF, Trenkle JM, Holz RW (1997) Punctate appearance of dopaminebeta-hydroxylase on the chromaffin cell surface reflects the fusion of individual chromaffin granules upon exocytosis. Neuroscience 80:847-860.

Zajac JM, Mollereau C (2006) RFamide peptides. Introduction. Peptides 27:941-942
Zhang Q, Fukuda M, Van Bockstaele E, Pascual O, Haydon PG (2004a) Synaptotagmin IV regulates glial glutamate release. Proc Natl Acad Sci U S A 101:9441-9446.

Zhang Q, Pangrsic T, Kreft M, Krzan M, Li N, Sul JY, Halassa M, Van Bockstaele E, Zorec R, Haydon PG (2004b) Fusion-related release of glutamate from astrocytes. J Biol Chem 279:12724-12733.

Zonta M, Sebelin A, Gobbo S, Fellin T, Pozzan T, Carmignoto G (2003) Glutamate-mediated cytosolic calcium oscillations regulate a pulsatile prostaglandin release from cultured rat astrocytes. J Physiol 553:407-414.

Zukowska-Grojec Z, Pruszczyk P, Colton C, Yao J, Shen GH, Myers AK, Wahlestedt C (1993) Mitogenic effect of neuropeptide Y in rat vascular smooth muscle cells. Peptides 14:263-268. 